\title{
Article \\ Thermochemical Energy Storage Performance Analysis of (Fe,Co,Mn)Ox Mixed Metal Oxides
}

\author{
Yabibal Getahun Dessie ${ }^{1}$, Qi Hong ${ }^{1, * \mathbb{C}}$, Bachirou Guene Lougou ${ }^{1,2, * \mathbb{C}}$, Juqi Zhang ${ }^{1}$, Boshu Jiang ${ }^{1}$, \\ Junaid Anees ${ }^{1} \mathbb{D}$ and Eyale Bayable Tegegne ${ }^{1}$ \\ 1 School of Energy Science and Engineering, Harbin Institute of Technology, Harbin 150001, China; \\ 18BF02071@stu.hit.edu.cn (Y.G.D.); zhangjq_hit@163.com (J.Z.); 19B902033@stu.hit.edu.cn (B.J.); \\ j.anees@hit.edu.cn (J.A.); eyale.bayable@aau.edu.et (E.B.T.) \\ 2 MIIT Key Laboratory of Critical Materials Technology for New Energy Conversion and Storage, \\ School of Chemistry and Chemical Engineering, Harbin Institute of Technology, Harbin 150001, China \\ * Correspondence: qihong@hit.edu.cn (Q.H.); 15bf02043@hit.edu.cn (B.G.L.)
}

check for updates

Citation: Dessie, Y.G.; Hong, Q.; Lougou, B.G.; Zhang, J.; Jiang, B.; Anees, J.; Tegegne, E.B.

Thermochemical Energy Storage Performance Analysis of (Fe,Co,Mn)Ox Mixed Metal Oxides. Catalysts 2021, 11, 362. https:// doi.org/10.3390/catal11030362

Academic Editor: Leonarda Francesca Liotta

Received: 22 January 2021

Accepted: 8 March 2021

Published: 10 March 2021

Publisher's Note: MDPI stays neutral with regard to jurisdictional claims in published maps and institutional affiliations.

Copyright: (c) 2021 by the authors. Licensee MDPI, Basel, Switzerland. This article is an open access article distributed under the terms and conditions of the Creative Commons Attribution (CC BY) license (https:// creativecommons.org/licenses/by/ $4.0 /)$.

\begin{abstract}
Metal oxide materials are known for their ability to store thermochemical energy through reversible redox reactions. Metal oxides provide a new category of materials with exceptional performance in terms of thermochemical energy storage, reaction stability and oxygen-exchange and uptake capabilities. However, these characteristics are predicated on the right combination of the metal oxide candidates. In this study, metal oxide materials consisting of pure oxides, like cobalt(II) oxide, manganese(II) oxide, and iron(II, III) oxide $\left(\mathrm{Fe}_{3} \mathrm{O}_{4}\right)$, and mixed oxides, such as (100 wt.\% $\mathrm{CoO}$, 100 wt. $\% \mathrm{Fe}_{3} \mathrm{O}_{4}, 100$ wt. $\% \mathrm{CoO}, 25$ wt. $\% \mathrm{MnO}+75$ wt. $\% \mathrm{CoO}, 75$ wt. $\% \mathrm{MnO}+25$ wt. $\% \mathrm{CoO}$ ) and 50 wt. $\% \mathrm{MnO}+50 . w t . \% \mathrm{CoO})$, which was subjected to a two-cycle redox reaction, was proposed. The various mixtures of metal oxide catalysts proposed were investigated through the thermogravimetric analysis (TGA), differential scanning calorimetry (DSC), energy dispersive X-ray (EDS), and scanning electron microscopy (SEM) analyses. The effect of argon (Ar) and oxygen $\left(\mathrm{O}_{2}\right)$ at different gas flow rates $(20,30$, and $50 \mathrm{~mL} / \mathrm{min})$ and temperature at thermal charging step and thermal discharging step $\left(30-1400{ }^{\circ} \mathrm{C}\right)$ during the redox reaction were investigated. It was revealed that on the overall, $50 \mathrm{wt} . \%$ $\mathrm{MnO}+50 \mathrm{wt} . \% \mathrm{CoO}$ oxide had the most stable thermal stability and oxygen exchange to uptake ratio ( 0.83 and 0.99 at first and second redox reaction cycles, respectively). In addition, $30 \mathrm{~mL} / \mathrm{min}$ $\mathrm{Ar}-20 \mathrm{~mL} / \mathrm{min} \mathrm{O}_{2}$ gas flow rate further increased the proposed ( $\left.\mathrm{Fe}, \mathrm{Co}, \mathrm{Mn}\right) \mathrm{Ox}$ mixed oxide catalyst's cyclic stability and oxygen uptake ratio. SEM revealed that the proposed (Fe,Co,Mn)Ox material had a smooth surface and consisted of polygonal-shaped structures. Thus, the proposed metallic oxide material can effectively be utilized for high-density thermochemical energy storage purposes. This study is of relevance to the power engineering industry and academia.
\end{abstract}

Keywords: thermochemical energy storage; (Fe,Co,Mn)Ox mixed oxide catalyst; energy density; redox kinetic; cyclic stability

\section{Introduction}

"Clean energy" is a major area of focus in this century. A related aspect is efficient energy storage development and utilization, which are necessitated by an increase in global energy demand and the deleterious effects of the use of fossil fuels to the environment. There is an array of renewable energy sources such as wind, tidal wave, biogas, hydro, and solar, which aim at providing electricity, with hydroelectric energy taking the lead. On the other hand, solar energy integration with thermal energy storage is a very important technology, particularly when the cost of electric supply and demand increases. Thus, thermal energy storage provides a means of continuous and stable energy supply. There are different solar energy concentrators developed to receive solar energy directly from the sun, or as radiation received by the heliostats, which is then reflected back to the solar receiver. In the latter case, the collected energy is taken to the energy storage reactor 
by means of heat transfer fluid (HTF). Energy storage can be achieved in different ways, such as sensible, latent, and phase change materials. Sensible energy storage depends on the internal energy of a material, which in turn depends on the material's heat capacity. Latent heat energy storage is possible when the material undergoes a phase change such as freezing or melting [1,2], whereas phase change materials (PCM) are possible due to absorption or release of energy by the material. Thermal energy storage (TES) that is integrated with concentrated solar power (CSP) [3-6], can be used when variable energy or electricity demand is high. Thermochemical energy storage (TCES) is an attractive and alternative means of solar storage at higher temperatures $\left(400-1200{ }^{\circ} \mathrm{C}\right)$. The hightemperature process associated with thermodynamic cycles facilitate the conversion of solar energy to electricity. TCES is advantageous in offering high energy density and a possibility of energy storage at room temperature using solid stable biomolecules. Pertaining to TCES application, there are oxides that were proven to show promising results for their energy storage capacity, such as metallic oxides [5,7-9], hydroxides, particularly calcium hydro oxides [10-16], and carbonate-made materials including calcium [17-19] and strontium carbonate $[20,21]$. However, these carbonates require structural stabilization to hinder sintering at high reaction temperature. $\mathrm{Co}_{3} \mathrm{O}_{4} / \mathrm{CoO}$ and $\mathrm{Mn}_{2} \mathrm{O}_{3} / \mathrm{Mn}_{3} \mathrm{O}_{4}$ are well known to be the most promising redox systems, while $\mathrm{CuO} / \mathrm{Cu}_{2} \mathrm{O}$ also show good properties for TCES application [22-28]. Cobalt metallic oxides provide fast reaction activity, complete reversibility, and high energy density with cyclic stability and transition temperature in CSP application $\left(892^{\circ} \mathrm{C}\right)$. Studies have implemented cobalt metallic oxides with CSP integrated reactor as an energy storage unit. Sing et al. [29] developed a numerical model that simulated the asserting heat and mass transfer performance of a cobalt-based material as a thermochemical storage system.

The aim of thermal energy storage application technology in solar thermal power system is to store solar energy as sensible, latent, and in PCM form or chemical forms, which can later be used for different energy demands particularly during low to non-sunshine hours. The dispatch ability [30] of TES and the nature of construction caused its demand to be increased. This study focused on the selection and characterization of materials with different proportion of metallic oxides that would be suitable for the development of thermochemical energy storage devices. The energy density capacity, cyclic stability, oxygen absorption, and release capacity of these were studied in the temperature range from 30 to $1400{ }^{\circ} \mathrm{C}$ and constant temperature supply was taken as the CSP power input. In the experimental analysis the endothermic and exothermic reaction with reversibility and cyclic stability were assessed. From Equations (1) and (2), heat was supplied to the compound to store solar energy in the form of chemical energy. When this system integrated with the CSP system, continuous energy production was possible in cloudy or dark skies [16-32]. The following Equations (1) and (2) can express the redox reactions mechanisms during charging-discharging processes. In the specific case of single metal oxides, air can be used as heat transfer fluid (Equations (1) and (2)), which allows operating with an open-loop system. The MO used in Equations (1) and (2) represents any metallic oxides.

$$
\begin{aligned}
& \mathrm{MO}_{(\text {ox })}+\text { Heat } \rightarrow \mathrm{MO}_{(\text {red })}+\alpha \mathrm{O}_{2(\mathrm{~g})} \\
& \mathrm{MO}_{(\text {red })}+\alpha \mathrm{O}_{2(\mathrm{~g})} \rightarrow \mathrm{MO}_{(\text {ox })}+\text { Heat }
\end{aligned}
$$

The use of metallic oxides as TES materials and air as heat transfer fluid can be advantageous in an open-loop system of solar energy harassing technology. The development of thermochemical solar energy storage mechanism, which depends on pressurized air-based solar tower receivers has attracted the attention of researchers. $\mathrm{CoO}$ and $\mathrm{Mn}_{3} \mathrm{O}_{4}$ are the most used oxide materials for thermochemical energy storage. Existing studies show that $\mathrm{Co}_{3} \mathrm{O}_{4}$ undergoes fast kinetic reaction, complete reaction, cyclic stability and has a gravimetric energy density of $576 \mathrm{~kJ} / \mathrm{kg}$ [33] and a theoretical enthalpy of $844 \mathrm{~kJ} / \mathrm{kg}$ [34-37]. However, the toxic nature cobalt oxides hamper their use. Studies have revealed that $\mathrm{Mn}_{2} \mathrm{O}_{3}$ occurs between $920-1000{ }^{\circ} \mathrm{C}$ with notable slow re-oxidation between $850-500{ }^{\circ} \mathrm{C}$ 
and it has an energy storage density range $110-160 \mathrm{~kJ} / \mathrm{kg}$ [38-40] and a theoretical enthalpy of $202 \mathrm{~kJ} / \mathrm{kg}$ [39].

Generally, optimization of material reactivity particularly metallic oxides can be enhanced by adopting strategies with proper synthesis control techniques for tailored morphology or stabilization of inert materials to reduce sintering effect. Improvement of reaction kinetics, reaction turning, and flexibility of a material can be obtained by the addition dopants, particularly in the case of the oxides of manganese, which are known to slow down reaction cycles. Doping effects of transition metals are also an option to slow redox reaction $[33,35]$.

The purpose of the present study is to investigate and identify the appropriate proportion of cobalt(II) oxide, manganese(II) oxide, and $\mathrm{Fe}_{3} \mathrm{O}_{4}$ that synthesizes a material with good cyclic stability, optimal redox reaction, and good oxygen absorption capacity, which are characteristics suitable for thermal energy storage purpose (TES). In this study, the best optimized metallic mixed oxides were tested and compared for their capability of energy density, the identification the optimized gas flow rates, the heat rates, cyclic stability and phase changing temperature were properly analyzed. These aforementioned parameters would assist in investigating how appropriate addition of transition metallic oxides improves the slow and the fast reaction to optimized [36] and sintering [41], loss-in-capacity over cycles [39] to decrease the reduction temperature lower so that at lower supply of energy can be effective for thermochemical energy storage capacity. Singh et al. [29] revealed that addition of iron on pure cobalt oxides or addition of cobalt oxides on iron slowed down chemical reaction kinetics of the mixed oxides and consequently lowered its enthalpy when compared to pure oxides. Pakoura et al. [40] that cobalt oxide with $10-20 \mathrm{wt} . \%$ of iron good thermo-mechanical stability over the temperature of redox cycles. Carrillow et al. [41] revealed that the iron does not prevent the sintering encountered by $\mathrm{Mn}_{2} \mathrm{O}_{3}$ but helps to increase the heat storage density of the material. Thus, the addition of iron helps to stabilize and enhance the oxidation rate of manganese oxide over repeating performance of redox cycles. According to their study, the fastest and most stable oxidation reaction was obtained by $\mathrm{Mn}_{2} \mathrm{O}_{3}$ doped $20 \mathrm{~mol} \% \mathrm{Fe}$. In another study, the author's also considered $\mathrm{Fe}-\mathrm{Cu} \mathrm{Co}$-doping in manganese oxide and that the incorporation of $\mathrm{Cu}$ decreased reduction temperature. However, the doping of iron to copper found to increase the r-oxidation temperature.

Recently models have been developed to provide thermodynamic descriptions of (Fe,Co,Mn)Ox [42-45] systems. Guene Lougou et al. [46-50] and Shuai [51,52] conducted studies on energy storage thermochemical reactor together with the synthesis of thermochemical energy storage material and Yabiabl et al. [53,54] studied about the impacts of thermochemical reactor designs for thermal energy storage and conversion of thermal efficiency. The researchers were able to produce a material that could resist the high-temperature thermal reduction super magnetic nanoparticles coated with aluminum ( $\mathrm{NiFe}_{2} \mathrm{O}_{4} @$ Alumina), $\left(\mathrm{NiFe}_{2} \mathrm{O}_{4} @ \mathrm{ZrO}_{2}\right)$, as well as support transits into new active phases including hercynite class materials $\left(\mathrm{FeNiAlO}_{4}\right.$ and $\left.\mathrm{FeAlO}_{4}\right)$, Fe-oxide phases $\left(\mathrm{Fe}_{2} \mathrm{O}_{3}, \mathrm{Fe}_{3} \mathrm{O}_{4}\right.$, and $\mathrm{FeO}$ ) and $\mathrm{NiO},(\mathrm{Ni}, \mathrm{Fe})$, and $\mathrm{AlNi}$ phases.

This present work is also aimed at oxygen storage and exchange capacity during mass loss and during redox reaction in the newly prepared $(\mathrm{Fe}, \mathrm{Co}, \mathrm{Mn}) \mathrm{Ox}$ material. The uptake and release capability of oxygen in each redox reaction cycle has been studied and the phase, reaction enthalpy, phase change, or the transition temperature for each metallic oxides have been compared. In developing the newly synthesized material, six metallic oxides were subjected to thermogravimetric analysis (TGA), scanning electron microscopy (SEM), differential scanning calorimetry (DSC), and energy dispersive X-ray (EDS) analysis. In addition, different atmospheric argon gas flow rates (20, 30, and 50 $\mathrm{mL} / \mathrm{min}$ ), oxygen flow rates $(20,30$, and $50 \mathrm{~mL} / \mathrm{min})$, and charging temperatures (30-1400 ${ }^{\circ} \mathrm{C}$ ) were studied and their effects on the newly developed thermochemical energy storage material were elucidated. 


\section{Result and Discussion}

\subsection{The TGA of Metallic Oxides during Redox Reactions}

From Figure 1a, all the TGA tested results are explained by weight loss \% with time of charging and discharging temperature. Figure 1 shows the two cycles that all six materials were heated from room temperature $\left(30 \rightarrow 1400{ }^{\circ} \mathrm{C} \rightarrow 800 \rightarrow 1400 \rightarrow 800{ }^{\circ} \mathrm{C}\right)$ and different results were observed during the test process. The results were identified using broken lines and stages. In the first stage, as the applied temperature increased for about $30 \mathrm{~min}$, all materials lost weight except $\mathrm{Fe}_{3} \mathrm{O}_{4}$. In this stage, the loss was mainly due to the dehydration of water. When the temperature reached $1400{ }^{\circ} \mathrm{C}$ in the second stage from 30 to $45 \mathrm{~min}$, except $\mathrm{Fe}_{3} \mathrm{O}_{4}$ which gained weight, other materials lost weight due to decomposition. In the third stage from 45 to $75 \mathrm{~min}$, all materials reacted with the oxygen molecules and gained weight. The process of weight gain continued even when the temperature decreased from 1400 to $800^{\circ} \mathrm{C}$ during the process of chemical reactions. The weight gained for $100 \mathrm{wt} . \% \mathrm{CoO}$ and $25 \mathrm{wt} . \% \mathrm{MnO}+75 \mathrm{wt} . \% \mathrm{CoO}$ were higher than other materials. In the fourth stage, from 75 to $105 \mathrm{~min}$, while the temperature remained at $800{ }^{\circ} \mathrm{C}$, the weight of $100 \mathrm{wt} . \% \mathrm{CoO}$ and $25 \mathrm{wt} . \% \mathrm{MnO}+75 \mathrm{wt} . \% \mathrm{CoO}$ increased while weights of other materials were constant. In the fifth stage, from 105 to $110 \mathrm{~min}$, the materials were re-heated from 800 to $1400{ }^{\circ} \mathrm{C}$ and all materials lost weight and the process was endothermic. In the sixth stage, at 110 to $130 \mathrm{~min}$, the materials were again cooled to $800{ }^{\circ} \mathrm{C}$ and the result indicated that all reactions gained weight. However, the weight gained by $100 \mathrm{wt} . \% \mathrm{Fe}_{3} \mathrm{O}_{4}, 100 \mathrm{wt} . \% \mathrm{CoO}$ and $25 \mathrm{wt} . \% \mathrm{MnO}+75 \mathrm{wt} . \% \mathrm{CoO}$ were greater than other materials, which underwent similar chemical reaction under the same conditions. As it can be seen in Figure $1 \mathrm{~b}$ for individual oxides, the reduction onset temperature for $\mathrm{Fe}-\mathrm{O}$ was higher than $\mathrm{CoO}$ and $\mathrm{MoO}\left(1061^{\circ} \mathrm{C}>465-1360^{\circ} \mathrm{C}>200-723{ }^{\circ} \mathrm{C}\right)$. However, the decomposition percentage for weight loss of $\mathrm{CoO}$ was far greater than $\mathrm{MnO}$ and $\mathrm{Fe}-\mathrm{O}$ $(6.27 \%>3.7 \%>0.31 \%)$. The re-oxidation onset temperature for $\mathrm{MnO}$ was a little bit greater than $\mathrm{Fe}-\mathrm{O}$ but higher than $\mathrm{CoO}$, which was $\left(1399{ }^{\circ} \mathrm{C}>1393>913\right)$, respectively. From Figure $1 \mathrm{~b}$, it is possible to conclude that $\mathrm{CoO}$ needs a high temperature for reduction followed by $\mathrm{Fe}_{3} \mathrm{O}_{4}$ as compared to $\mathrm{MnO}$. From Figure 1c the $50 \mathrm{wt} . \% \mathrm{MnO}+50 \mathrm{wt} . \% \mathrm{CoO}$ underwent for the two step redox reaction and Figure 1c shows the TGA results for the mixed metallic oxides of $50 \mathrm{wt} . \% \mathrm{MnO}+50 \mathrm{wt} . \% \mathrm{CoO}$ and $25 \mathrm{wt} . \% \mathrm{MnO}+75 \mathrm{wt} . \% \mathrm{CoO}$. After for $23 \mathrm{~min}, 25 \mathrm{wt} . \% \mathrm{MnO}+75 \mathrm{wt} . \% \mathrm{CoO}$ recorded a higher weight loss than $50 \mathrm{wt} . \%$ $\mathrm{MnO}+50 \mathrm{wt} . \% \mathrm{CoO}$. From 23 to $40 \mathrm{~min}$ of, the weight loss of $50 \mathrm{wt} . \% \mathrm{MnO}+50 \mathrm{wt} . \% \mathrm{CoO}$ was slightly higher than that of $25 \mathrm{wt} . \% \mathrm{MnO}+75 \mathrm{wt} . \% \mathrm{CoO}$. From 40 to $180 \mathrm{~min}$ for both processes as it was observed in Figure 1c, $50 \mathrm{wt} . \% \mathrm{MnO}+50 \mathrm{wt} . \% \mathrm{CoO}$ was more stable than $25 \mathrm{wt} . \% \mathrm{MnO}+75 \mathrm{wt} . \% \mathrm{CoO}$. Thus, from the abovementioned results and findings, 50 wt. $\% \mathrm{MnO}+50 \mathrm{wt} . \% \mathrm{CoO}$ was found the most stable compared to other metallic oxides. Figure $1 \mathrm{c}$ also depicted the temperature at thermal charging step and thermal discharging step during the process. Figure 1d shows the TGA for all computed metallic oxides. From that Figure 1d, $\mathrm{Fe}_{3} \mathrm{O}_{4}$ was the least decomposed; $\mathrm{CoO}$ underwent a single stage of decomposition, whereas others underwent multi-decomposition stages during the charging process in the first cycle redox reaction. From Figure 1e, $\mathrm{CoO}$ underwent an almost single visible stage of reduction and a single stage of dehydration, whereas Figure 1d indicated that $\mathrm{MnO}$ underwent multi-stage decomposition. Figure 1e shows the iron reduction reaction events during cycle 1. During the process of $\mathrm{Fe}_{3} \mathrm{O}_{4}$ reduction, the dehydration led to $0.31 \%$ weight loss, which was smaller than those of $\mathrm{MnO}$ and $\mathrm{CoO}$. In the charging of $\mathrm{Fe}_{3} \mathrm{O}_{4}$ to $1400{ }^{\circ} \mathrm{C}$, the weight kept increasing until about $1200{ }^{\circ} \mathrm{C}$. Figure $1 \mathrm{~h}$ depicted the $25 \mathrm{wt} . \% \mathrm{MnO}+75 \mathrm{wt} . \% \mathrm{CoO}$ underwent for first step of redox reaction and depicted the $2.52 \%$ of the initial weight probably lost due to evaporation and $5.47 \%$ of the weight was due to decomposition. Figure $1 \mathrm{~h}$ depicted multi-stage decomposition. Figure $1 \mathrm{i}$ depicted the TGA with temperature and the percentage loss for $75 \mathrm{wt} . \% \mathrm{MnO}+$ $25 \mathrm{wt} . \% \mathrm{CoO}$ were 5.565 in the first stage and 3.775 in the second stage. Figure $1 \mathrm{i}$ showed the first stage of decomposition was higher than the second stage. This was due to the content of $\mathrm{MnO}$ being higher than $\mathrm{CoO}$, and $\mathrm{CoO}$ is more vulnerable for decomposition 
than $\mathrm{MnO}$. Figure $1 \mathrm{j}$ depicted the redox for $50 \mathrm{wt} . \% \mathrm{MnO}+50 \mathrm{wt} . \% \mathrm{CoO}$. As it has been seen from Figure $1 \mathrm{j}$ the percentage loss were 3.91 and 3.67 in the first- and second-stage decomposition, respectively. Figure $1 \mathrm{k}$ shows the TGA for $25 \mathrm{wt} . \% \mathrm{MnO}+75 \mathrm{wt} . \% \mathrm{CoO}$ and $50 \mathrm{wt} . \% \mathrm{MnO}+50 \mathrm{wt} . \% \mathrm{CoO}$. From Figure 1k, it was noted that charging temperature (applied temperature) from 30 to $1400{ }^{\circ} \mathrm{C}$ with $30{ }^{\circ} \mathrm{C} / \mathrm{min}$ heating rate led to a significant reduction of $30 \mathrm{~mL} / \mathrm{min} \mathrm{Ar}$ and $/ \mathrm{min} \mathrm{O}_{2}, 25 \mathrm{wt} . \% \mathrm{MnO}+75 \mathrm{wt} . \% \mathrm{CoO}$, and all developed significant plateauing in reduction values of $50 \mathrm{wt} . \% \mathrm{MnO}+50 \mathrm{wt} . \% \mathrm{CoO}$ around $1000{ }^{\circ} \mathrm{C}$.

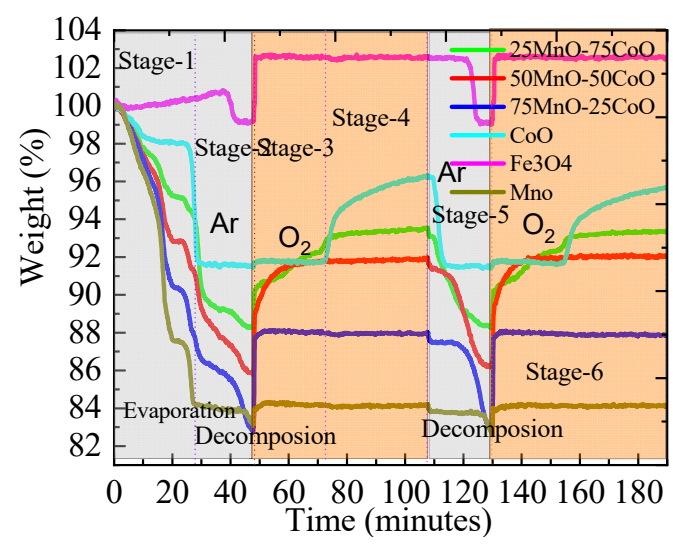

(a)

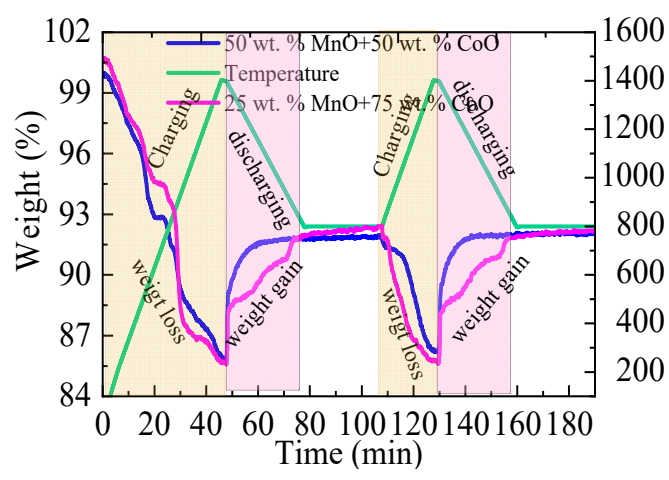

(c)

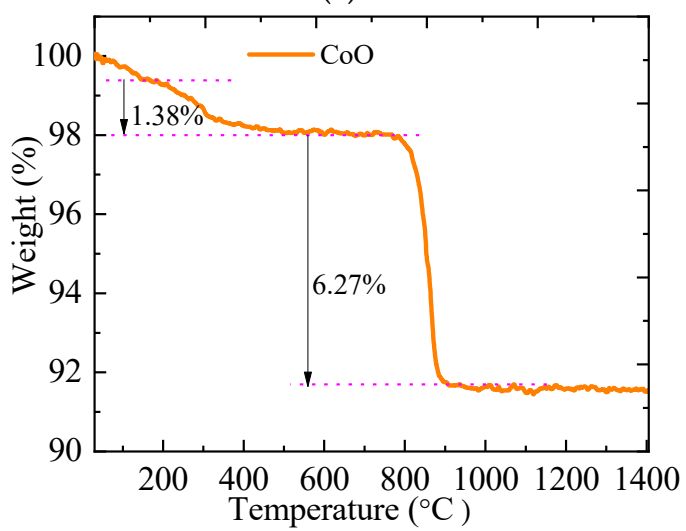

(e)

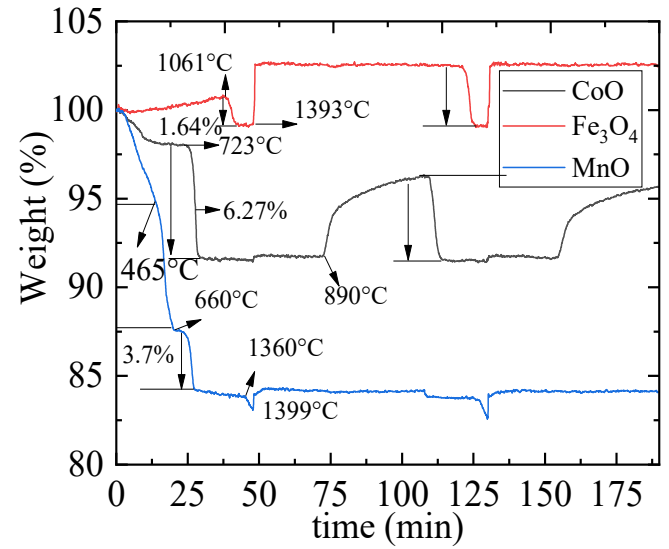

(b)

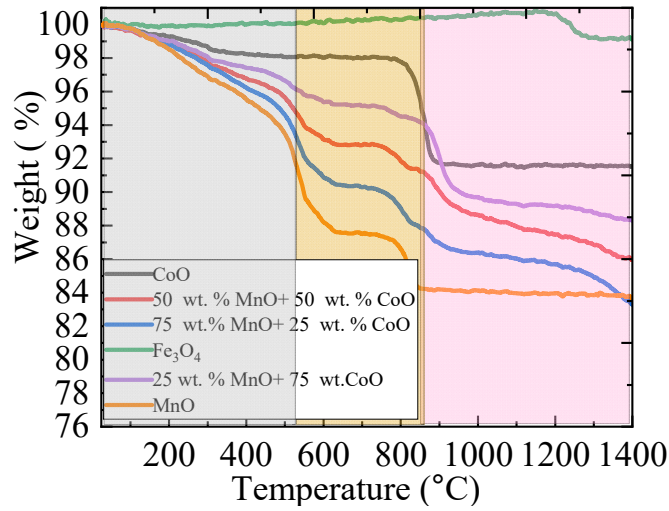

(d)

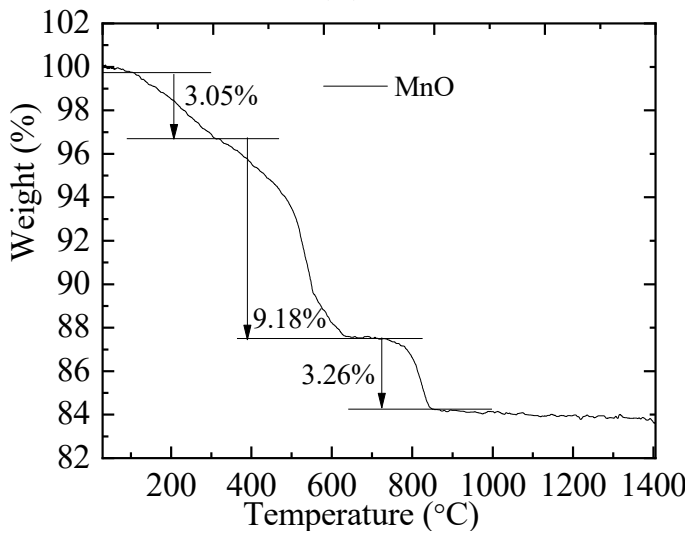

(f)

Figure 1. Cont. 


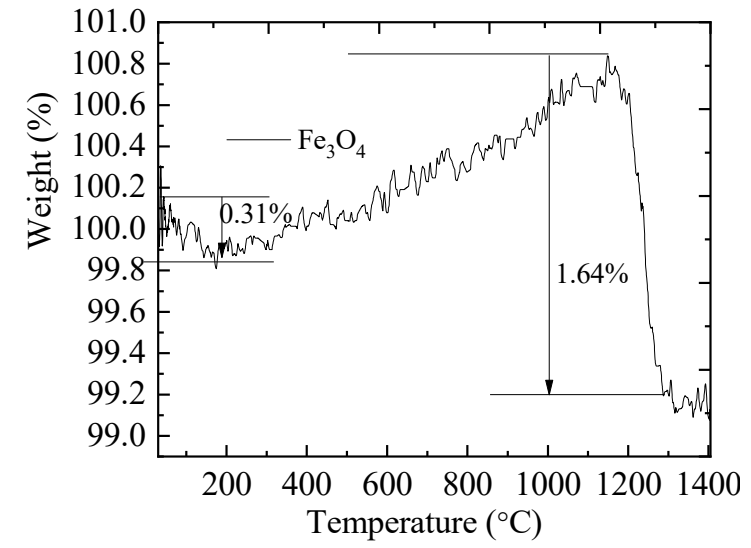

(g)

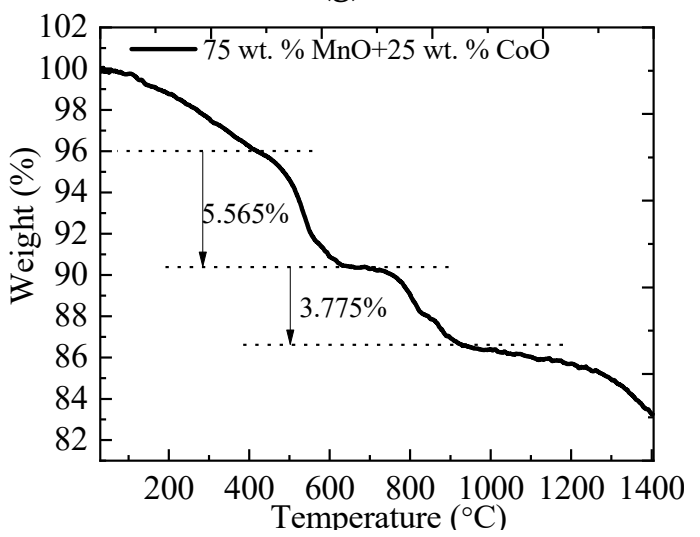

(i)

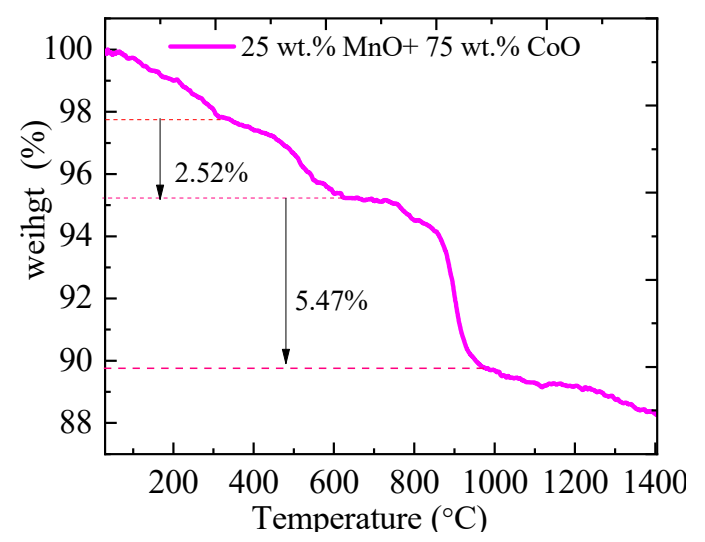

(h)

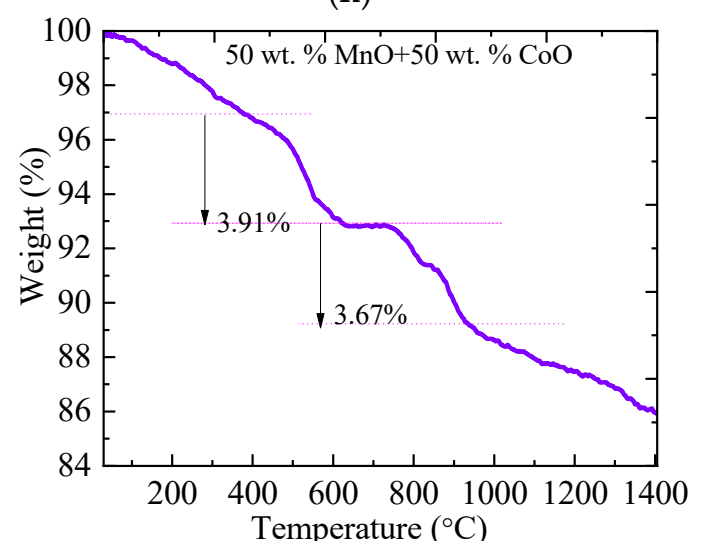

(j)

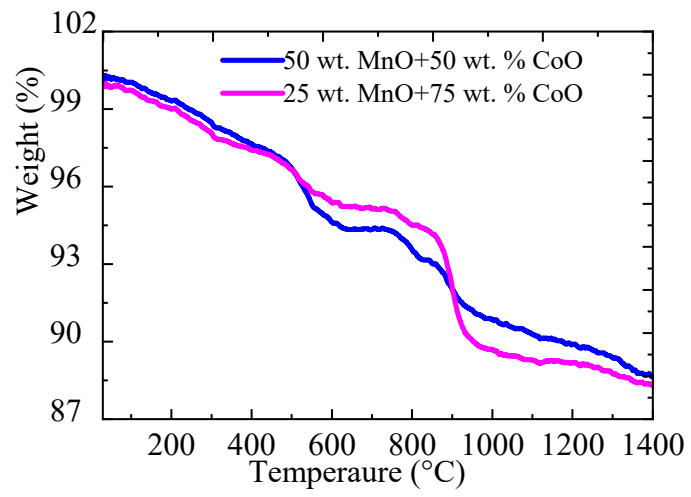

(k)

Figure 1. The TGA on mixed and pure metallic oxides at $30 \mathrm{~mL} \mathrm{Ar} / \mathrm{min}$ and $20 \mathrm{~mL} \mathrm{O} / \mathrm{min}$ gas flow rates and $30{ }^{\circ} \mathrm{C} / \mathrm{min}$ heating rate with applying temperature from room to $1400^{\circ} \mathrm{C}$ and cooling to $800^{\circ} \mathrm{C}$ for two step redox reaction: (a) TGA for two- step cyclic redox reaction for all oxides with time; (b) TGA for pure oxides with time; (c) TGA for mixed oxides that shows redox with time; (d) TGA for all oxides in the test with temperature in the first step of redox; (e) TGA for CoO with temperature in the first step of redox; (f) TGA for $\mathrm{MnO}$ with temperature in the first step of redox; (g) $\mathrm{TGA} \mathrm{for} \mathrm{Fe}_{3} \mathrm{O}_{4}$ with temperature in the first step of redox; (h) TGA for $25 \mathrm{wt} . \% \mathrm{MnO}+75 \mathrm{wt} . \% \mathrm{CoO}$ with temperature in the first step of redox; (i) TGA for $75 \mathrm{wt} . \% \mathrm{MnO}+25 \mathrm{wt} \% \mathrm{CoO}$ with temperature in the first step of redox; (j) TGA for $50 \mathrm{wt} . \% \mathrm{MnO}+50 \mathrm{wt} . \%$ $\mathrm{CoO}$ with temperature in the first step of redox; (k) TGA for $50 \mathrm{wt} . \% \mathrm{MnO}+50 \mathrm{wt} . \% \mathrm{CoO}$ and $25 \mathrm{wt} . \% \mathrm{MnO}+75 \mathrm{wt} . \%$ $\mathrm{CoO}$ with tempertaure.

2.2. The Phase Change Conditions Using Weight Derivative Graphs (WDG) on Metallic Oxides during the Redox Reaction

Figure 2a shows the derivative weight for all metallic oxides with charging temperature in the first cycle redox reaction. From that figure, it was noted that unlike iron oxide, which had a phase change temperature occurring at $>1200{ }^{\circ} \mathrm{C}$, for other metallic oxides, 
which were considered in this study, phase change temperature gaps were observed at $400-600{ }^{\circ} \mathrm{C}$ and $750-1000{ }^{\circ} \mathrm{C}$. Figure $2 \mathrm{~b}$ shows the weight derivative of $75 \mathrm{wt} . \% \mathrm{MnO}+$ $25 \mathrm{wt} . \% \mathrm{CoO}$ with room to $1400{ }^{\circ} \mathrm{C}$ in the first cycle, which revealed that phase changes occurred at $528{ }^{\circ} \mathrm{C}$ and $801^{\circ} \mathrm{C}$, respectively. However, it was difficult to show the changing phase reaction products in the TGA analysis because it needs further investigation, like XRD tests for checking whether the phase changing temperatures, which were observed in TGA, belong to reactants products, and what types of products are observed. From Figure $2 \mathrm{c}$, the phase change of $50 \mathrm{wt} . \% \mathrm{MnO}+50 \mathrm{wt} . \% \mathrm{CoO}$ was observed at $527^{\circ} \mathrm{C}$ and $893^{\circ} \mathrm{C}$, but the reduction of the compound started at $400{ }^{\circ} \mathrm{C}$ and Figure $2 \mathrm{c}$ clearly shows the stability of the redox reaction in both the second and first steps of the process. From Figure $2 \mathrm{~d}$, the derivative weight graph with temperature depicted that the phase change of $25 \mathrm{wt} . \% \mathrm{MnO}+75 \mathrm{wt} . \% \mathrm{CoO}$ occurred at $902{ }^{\circ} \mathrm{C}$ and reduction of the oxide started at $688^{\circ} \mathrm{C}$. The phase change indicating the critical curve for $25 \mathrm{wt} . \% \mathrm{MnO}+75 \mathrm{wt} . \% \mathrm{CoO}$ was sharper than that of $50 \mathrm{wt} . \% \mathrm{MnO}+50 \mathrm{wt} . \% \mathrm{CoO}$, specifically at the second turning curve, which indicated that higher weight losses occurred at this stage. From Figure 2e, the first stage of the derivative weight loss curve of $\mathrm{MnO}$ depicted that the weight loss was due to evaporation of water, the second events were observed at $529^{\circ} \mathrm{C}$ and $830^{\circ} \mathrm{C}$, respectively, which were the phase change temperatures of $\mathrm{MnO}$. From Figure $2 \mathrm{f}$, the first stage of the reduction step of $\mathrm{CoO}$ curve revealed that dehydration occurred. The onset temperature for the reduction was observed at $723^{\circ} \mathrm{C}$ and the phase change occurred at $845^{\circ} \mathrm{C}$. From Figure $2 \mathrm{~g}$, in the first stages from 200 to $450{ }^{\circ} \mathrm{C}, \mathrm{Fe}_{3} \mathrm{O}_{4}$ lost its weight by $0.31 \%$, which was also seen in Figure $1 \mathrm{~g}$, and decomposition of the iron oxide started around $1061^{\circ} \mathrm{C}$ and changed its phase around $1245^{\circ} \mathrm{C}$. From Figure $2 \mathrm{~b}-\mathrm{d}$, the derivative mixed oxides analysis revealed that the reduction of $50 \mathrm{wt} . \% \mathrm{MnO}+50 \mathrm{wt} . \% \mathrm{CoO}, 75 \mathrm{wt} . \% \mathrm{MnO}$ + $25 \mathrm{wt} . \% \mathrm{CoO}$ and $25 \mathrm{wt} . \% \mathrm{MnO}+75 \mathrm{wt} . \% \mathrm{CoO}$ took place at $400{ }^{\circ} \mathrm{C}, 410{ }^{\circ} \mathrm{C}$, and $688^{\circ} \mathrm{C}$, respectively. From Figure 1b, under Section 3.1, it was seen that the reduction temperatures for $\mathrm{MnO}$ and $\mathrm{CoO}$ occurred at the same heating and gases flow rates $\left(400{ }^{\circ} \mathrm{C}\right.$ and $723^{\circ} \mathrm{C}$, respectively), which were similar to those of mixed oxides of $50 \mathrm{wt} . \% \mathrm{MnO}+50 \mathrm{wt} . \%$ $\mathrm{CoO}$. However, the reduction onset temperature for $50 \mathrm{wt} . \% \mathrm{MnO}+50 \mathrm{wt} . \% \mathrm{CoO}$ was less than the parent oxides ( $\mathrm{MnO}$ and $\mathrm{CoO}$ ), which was about $420^{\circ} \mathrm{C}$ as observed in Figure 2c. However, other mixed oxides revealed higher onset reduction temperatures particularly oxides with more proportion weight of $\mathrm{CoO}$. Figure $2 \mathrm{~h}$ shows the derivative weight for $50 \mathrm{wt} . \% \mathrm{MnO}+50 \mathrm{wt} . \% \mathrm{CoO}$ and $25 \mathrm{wt} . \% \mathrm{MnO}+75 \mathrm{wt} . \% \mathrm{CoO}$. As it has been described in Section 3.1 Figure 1k, Figure $2 \mathrm{~h}$ also indicates that the $50 \mathrm{wt} . \% \mathrm{MnO}+50 \mathrm{wt} . \% \mathrm{CoO}$ was more stable during the reduction-oxidation reactions.

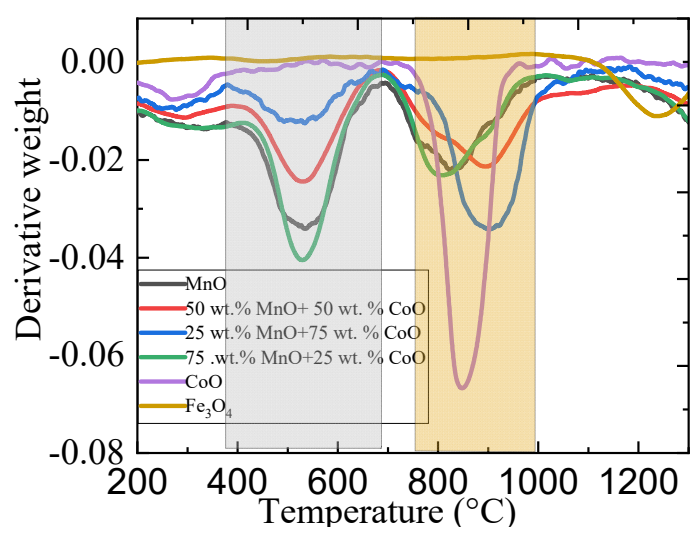

(a)

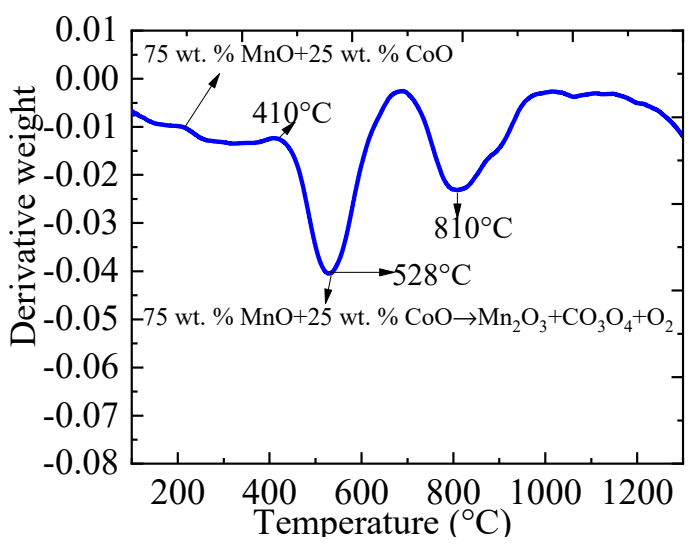

(b)

Figure 2. Cont. 


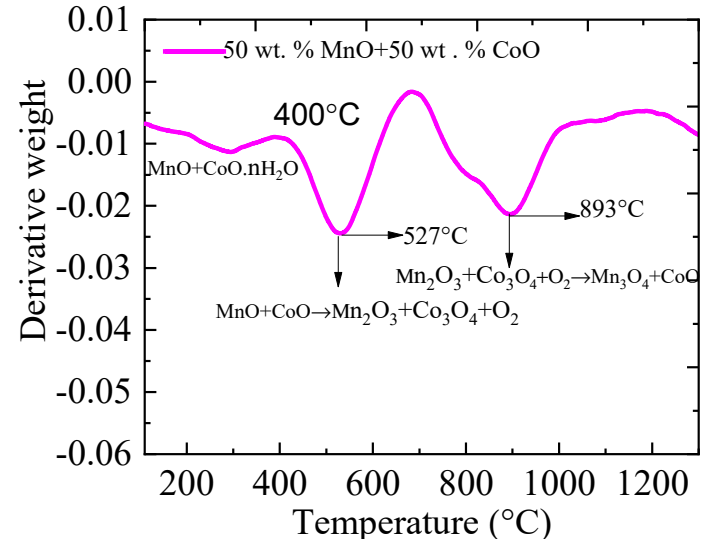

(c)

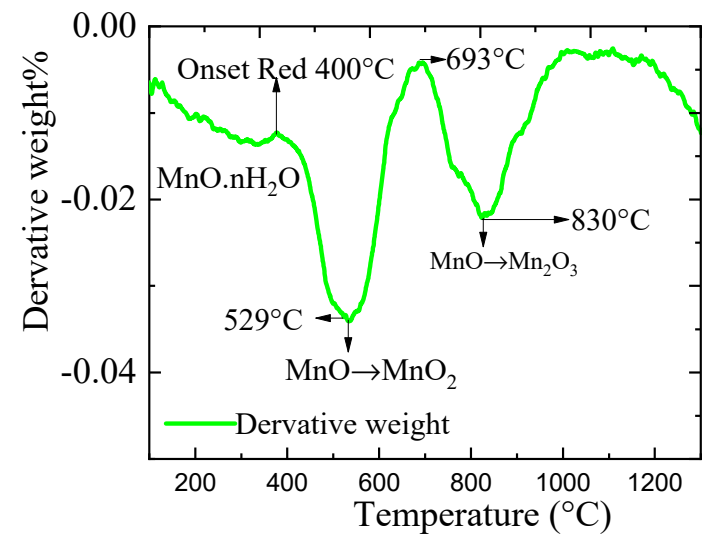

(e)

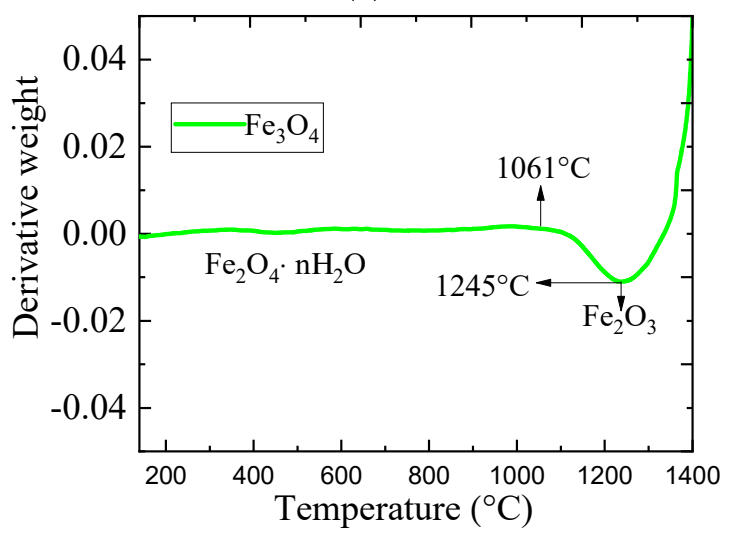

(g)

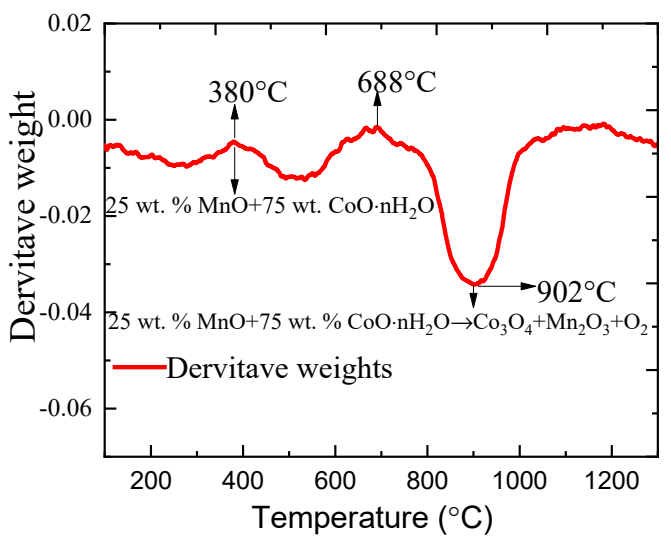

(d)

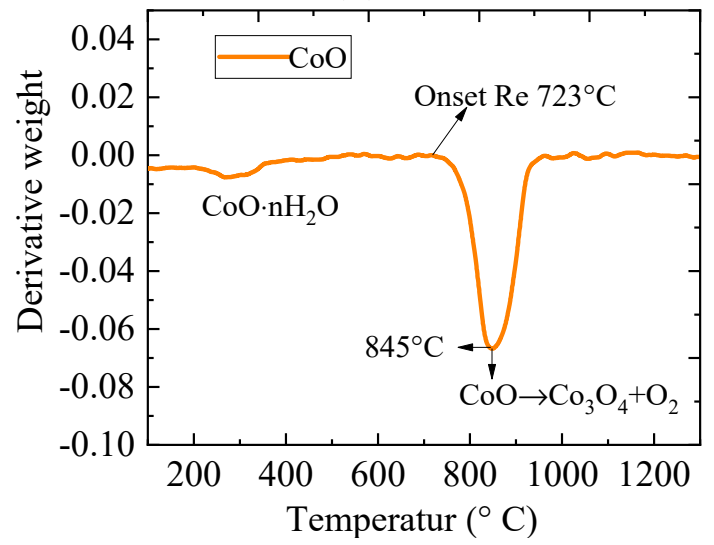

(f)

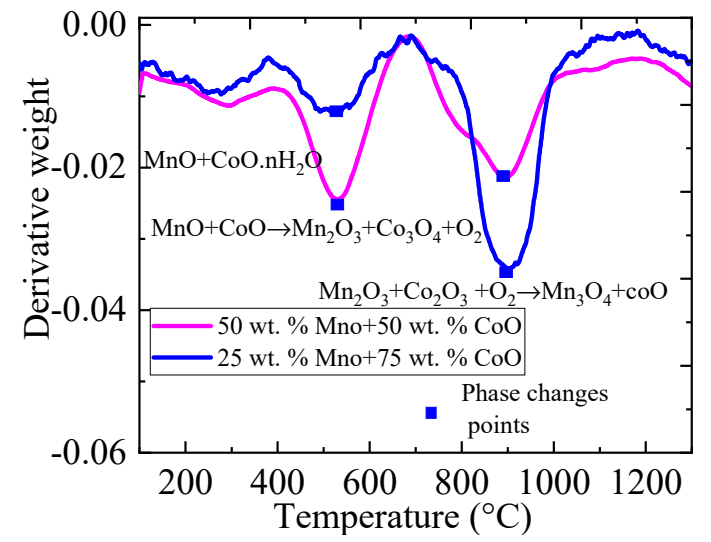

(h)

Figure 2. Weight derivative graphs (WDG) for mixed and pure metallic oxides at $30 \mathrm{~mL} \mathrm{Ar} / \mathrm{min}$ and $20 \mathrm{~mL} \mathrm{O} / 2 \mathrm{~min}$ gas flow rates subjected to heating from 30 to $1400{ }^{\circ} \mathrm{C}$ (at $30{ }^{\circ} \mathrm{C} / \mathrm{min}$ heating rate) step 1 redox: (a) WDG for all oxides under the test; (b) WDG for mixed oxides of $75 \mathrm{wt} . \% \mathrm{MnO}+25 \mathrm{wt} . \% \mathrm{CoO}$ with temperature; (c) WDG for mixed oxides of $50 \mathrm{wt} . \%$ $\mathrm{MnO}+50$ wt. $\% \mathrm{CoO}$ with temperature; (d) WDG for mixed oxides of 25 wt. $\% \mathrm{MnO}+75$ wt. $\%$ CoO with temperature; (e) $t$ WDG for $\mathrm{MnO}$ with temperature; (f) WDG for $\mathrm{CoO}$ with temperature; (g) WDG for $\mathrm{Fe}_{3} \mathrm{O}_{4} \mathrm{CoO}$ with temperature; (h) WDG $\mathrm{t}$ for mixed oxides of $25 \mathrm{wt} . \% \mathrm{MnO}+75 \mathrm{wt} . \% \mathrm{CoO}$ and $50 \mathrm{wt} . \% \mathrm{MnO}+50 \mathrm{wt} . \% \mathrm{CoO}$ with temperature in the first step of redox.

\subsection{The Thermal Performance and the Oxygen Uptake of Metallic Oxides}

\subsubsection{The Thermal Performance of Metallic Oxides}

Figure 3a shows the enthalpy accumulated for two-step cyclic redox reaction of all the metallic oxides. During the charging and discharging process $\mathrm{Fe}_{3} \mathrm{O}_{4}, \mathrm{MnO}$, and 50 wt. \% $\mathrm{MnO}+50$ wt. $\%$ CoO had large enthalpies, particularly during discharging, 50 wt. $\% \mathrm{MnO}+$ 
$50 \mathrm{wt} . \% \mathrm{CoO}$ had a higher enthalpy than other pure and mixed metallic oxides. Figure $3 \mathrm{~b}-\mathrm{d}$ shows the conversion rate efficiency of the metallic oxides. Figure $3 \mathrm{~b}$ shows the conversion rate of the metallic oxides during the heating from room to temperature $1400{ }^{\circ} \mathrm{C}$ in the first cycle, of redox reaction. Figure 3 c shows conversion rates of all the metallic oxides during the entire cycle redox reaction with time and Figure $3 \mathrm{~d}$ shows the conversion rate and the TGA of $50 \mathrm{wt} . \% \mathrm{MnO}+50 \mathrm{wt} . \% \mathrm{CoO}$ in the first cycle of the redox reaction. Thus, from Figure $3 \mathrm{~b}-\mathrm{d}, 50 \mathrm{wt} . \% \mathrm{MnO}+50 \mathrm{wt} . \% \mathrm{CoO}$ had stable conversion effect in the redox reaction while $\mathrm{CoO}$ had unstable conversion rate in both cycles of the redox reaction. Table 1 shows the onset temperature for reduction, conversion, enthalpy, and phase change temperature of all the metallic oxides during the charging stage in the first cycle. From that table, 50 wt. $\% \mathrm{MnO}+50 \mathrm{wt} . \% \mathrm{CoO}$ had the highest conversion and iron oxide had the highest phase change temperature. Table 2 shows the specific energy contents for all the metallic oxides at $952{ }^{\circ} \mathrm{C}$ in both the first and second reaction steps. From Table 2, at $952{ }^{\circ} \mathrm{C}$ in the first cycle redox reaction, $\mathrm{MnO}, \mathrm{CoO}, 50 \mathrm{wt} . \% \mathrm{MnO}+50 \mathrm{wt} . \% \mathrm{CoO}$, and $\mathrm{Fe}_{3} \mathrm{O}_{4}$ had reduction to oxidation percentage ratio of $24.2 \%, 17.7 \%, 16.7 \%$, and $16 \%$, respectively, whereas 50 wt. $\% \mathrm{MnO}+50$ wt. $\% \mathrm{CoO}, \mathrm{MnO}$ and $\mathrm{Fe}_{3} \mathrm{O}_{4}$ had reduction to oxidation of specific energy density ratio $41.5 \%, 55.2 \%, 48.2 \%$, respectively during the second redox cycle. From Table 2 , it was observed that the second cycle redox reaction had more energy exchange than the first had and $25 \mathrm{wt} . \% \mathrm{MnO}+75 \mathrm{wt} . \% \mathrm{CoO}$ had the least specific energy density ratio at 952 ${ }^{\circ} \mathrm{C}(6.7 \mathrm{~kJ} / \mathrm{g}$ and $23.1 \mathrm{~kJ} / \mathrm{g})$ in the first and second cycle, respectively. Figure $3 e$ shows the endothermic and exothermic phases of $50 \mathrm{wt} . \% \mathrm{MnO}+50 \mathrm{wt} . \% \mathrm{CoO}$ during redox reaction in the first cycle.

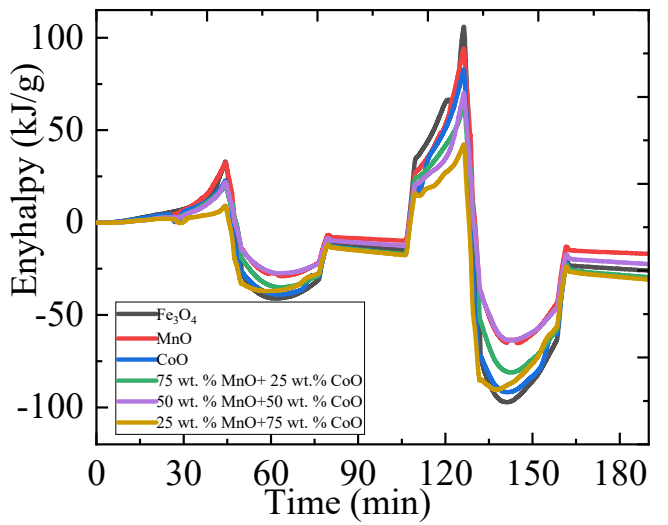

(a)

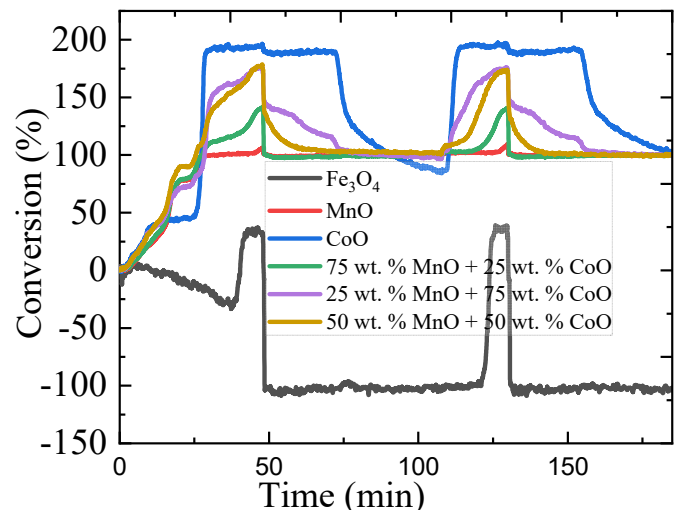

(c)

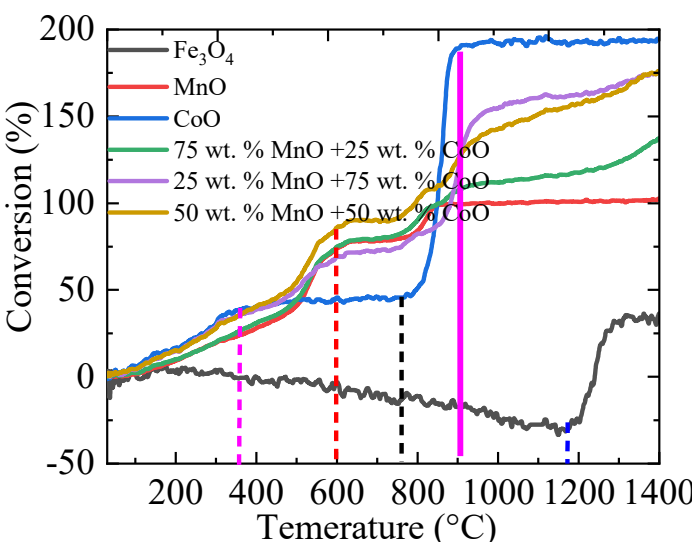

(b)

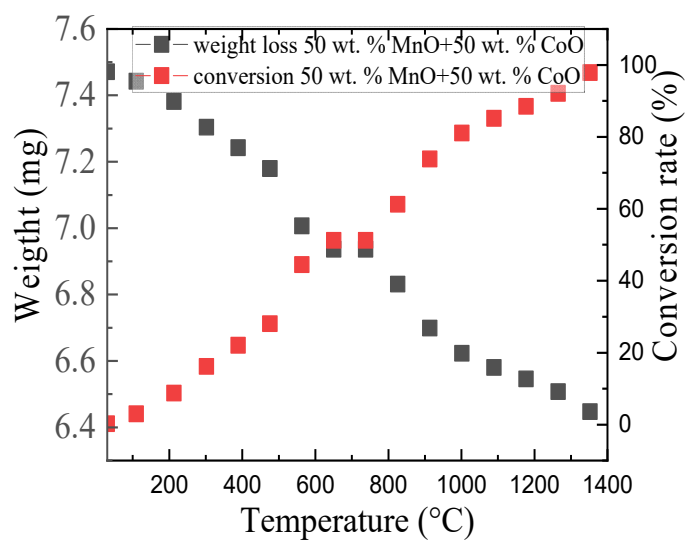

(d)

Figure 3. Cont. 


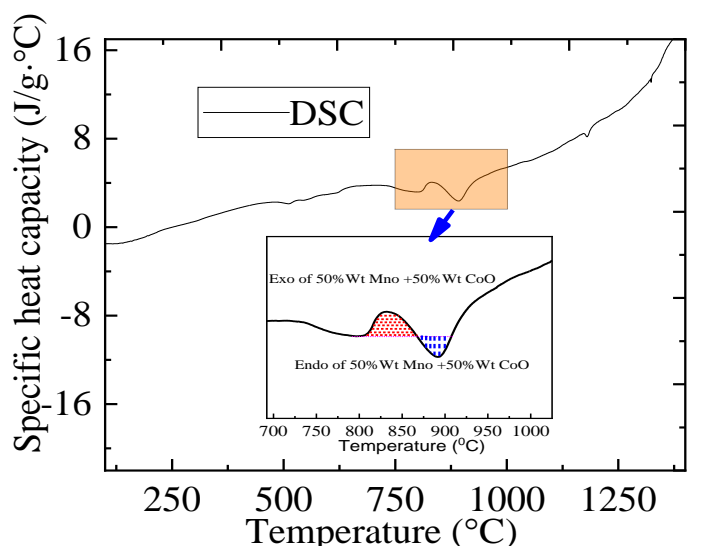

(e)

Figure 3. The thermal performance of mixed and pure oxide during the experiment at $30 \mathrm{~mL} \mathrm{Ar} / \mathrm{min}$ and $20 \mathrm{~mL} \mathrm{O} 2 / \mathrm{min}$ gas flow rates subjected to heating from 30 to $1400{ }^{\circ} \mathrm{C}$ at $30{ }^{\circ} \mathrm{C} / \mathrm{min}$ heating rate and cooling to $800{ }^{\circ} \mathrm{C}$ for two-cyclic redox reactions: (a) The oxygen uptake ratio in both cyclic redox reactions; (b) the enthalpy for mixed all oxides under test; (c) the conversion performance of all oxides under state (d) conversion performance for all oxides under the test with time; (e) specific heat capacity for $50 \mathrm{wt} . \% \mathrm{MnO}+50 \mathrm{wt} . \% \mathrm{CoO}$ with temperature.

Table 1. Physical properties during charging from 25 to $1400{ }^{\circ} \mathrm{C}$ with rounding to three digit [55].

\begin{tabular}{|c|c|c|c|c|c|}
\hline \multirow{2}{*}{ Material } & \multirow{2}{*}{$\begin{array}{c}\text { Onset } \\
\text { Temperature } \\
\text { Reduction }\left({ }^{\circ} \mathrm{C}\right)\end{array}$} & \multirow{2}{*}{ Conversion } & \multicolumn{2}{|c|}{ Enthalpy (J/g) } & \multirow{2}{*}{$\begin{array}{l}\text { Phase Changing } \\
\text { Temperature }\left({ }^{\circ} \mathrm{C}\right)\end{array}$} \\
\hline & & & Crystallization & Melting & \\
\hline 50 wt. $\% \mathrm{MnO}+50$ wt. $\% \mathrm{CoO}$ & 406 & 92.340 & 28 & 30 & $530-895$ \\
\hline 25 wt. $\% \mathrm{MnO}+75$ wt. $\% \mathrm{CoO}$ & 395 & 87.500 & No observation & 403 & $518-905$ \\
\hline 75 wt. $\% \mathrm{MnO}+25$ wt. $\% \mathrm{CoO}$ & 425 & 87.600 & 13 & 8 & $529-808$ \\
\hline $\mathrm{CoO}$ & 720 & 86.00 & No observation & 284.70 & 850 \\
\hline $\mathrm{MnO}$ & 400 & 83.800 & No observation & 33 & $525-834$ \\
\hline $\mathrm{Fe}_{3} \mathrm{O}_{4}$ & 1063 & 90.400 & No observation & 28 & 1245 \\
\hline
\end{tabular}

Table 2. Specific energy content in $\mathrm{kJ} / \mathrm{g}$ of reduction (charging) and oxidation (discharging) steps of the six materials.

\begin{tabular}{|c|c|c|c|c|c|c|}
\hline \multirow{3}{*}{ Material } & \multicolumn{4}{|c|}{ Energy Content in $\mathrm{kJ} / \mathrm{g}$ at $952{ }^{\circ} \mathrm{C}$} & \multirow{2}{*}{\multicolumn{2}{|c|}{$\begin{array}{c}\mathrm{O}_{2} / \mathrm{O}_{2} \\
\text { Ratio of Energy Uptake to Energy } \\
\text { Release at } 952{ }^{\circ} \mathrm{C} \text { in } \%\end{array}$}} \\
\hline & \multicolumn{2}{|c|}{ Cycle 1} & \multicolumn{2}{|c|}{ Cycle 2} & & \\
\hline & Reduction & Oxidation & Reduction & Oxidation & Cycle 1 & Cycle 2 \\
\hline 50 wt. $\% \mathrm{MnO}+50$ wt. $\% \mathrm{CoO}$ & 4.4 & 26.300 & 23.800 & 57.300 & 16.700 & 41.500 \\
\hline 25 wt. $\% \mathrm{MnO}+75$ wt. $\% \mathrm{CoO}$ & 2.2 & 33 & 16.400 & 71 & 6.700 & 23.100 \\
\hline 75 wt. $\% \mathrm{MnO}+25$ wt. $\% \mathrm{CoO}$ & 4.2 & 32.400 & 25.500 & 73 & 12.960 & 34.900 \\
\hline $\mathrm{CoO}$ & 6.4 & 36.700 & 23.900 & 80.90 & 17.400 & 29.500 \\
\hline $\mathrm{MnO}$ & 6 & 27.300 & 32 & 58 & 24.200 & 55.200 \\
\hline $\mathrm{Fe}_{3} \mathrm{O}_{4}$ & 6.4 & 40 & 39.500 & 82 & 16 & 48.200 \\
\hline
\end{tabular}

However, the standard enthalpy values for iron(II, III) oxide, Mn(II) oxide and Co(II) are $-1118.4,-248.9$ and $-237.9 \mathrm{~kJ}$ respectively.

\subsubsection{The Oxygen Storage Capacity of Metallic Oxides}

Figure 4 shows the efficiency for oxygen uptake and release ratio during redox reactions. The uptake and release of oxygen by all the metallic oxides during the two-cycle re-dox reaction derived from TGA are shown in Table 3. $\mathrm{Fe}_{3} \mathrm{O}_{4}, 50$ wt. $\% \mathrm{MnO}+50$ wt. $\%$ $\mathrm{CoO}$, and 25 wt. $\% \mathrm{MnO}+75$ wt. $\% \mathrm{CoO}$ had oxygen uptake values of 2.1, 0.830, and 0.760, respectively in the first cycle and 0.997, 0.996, and 0.960, respectively in the second cycle. Increase in oxygen uptake implies increase in energy storage. Thus, this finding indicates 
that the aforementioned materials had good energy storage efficiency. For the mixed oxides, $50 \mathrm{wt} . \% \mathrm{MnO}+50 \mathrm{wt} . \% \mathrm{CoO}$ was found to have good thermochemical energy storage capacity as its oxygen uptake to release ratio values in both cycles were 0.830 and 0.996 . For the pure oxides, iron oxides had the highest oxygen uptake in both cycles ( 2.1 and 0.997). This result related to the findings in Sections 3.1 and 3.2, which revealed that the mass of iron oxide increased during the charging stage. Figure 3 shows the efficiency of oxygen uptake capacity of the pure metallic and mixed oxides. According to that figure and Table 2, iron oxide had the highest oxygen uptake in the first cycle. As revealed, oxygen uptake capacity ratio of 0.86 , and 0.96 in the first and second cycles, respectively. Thus, $50 \mathrm{wt} . \% \mathrm{MnO}+50 \mathrm{wt} . \% \mathrm{CoO}$ was selected for the next stage, which involved both stability and energy capacity analysis, and $\mathrm{Fe}_{3} \mathrm{O}_{4}$ had the oxygen uptake to oxygen release capacity ratio $(2.1,0.997)$ cycle 1 and cycle 2 during redox, respectively.

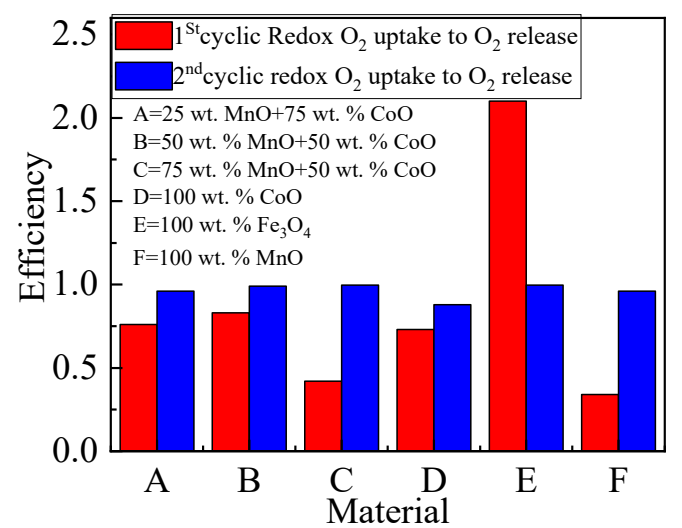

Figure 4. The oxygen uptake ratio in both cyclic redox reactions at $30 \mathrm{~mL} \mathrm{Ar} / \mathrm{min}$ and $20 \mathrm{~mL} \mathrm{O} 2 / \mathrm{min}$ gas flow rates subjected to heating from 30 to $1400{ }^{\circ} \mathrm{C}$ at $30{ }^{\circ} \mathrm{C} / \mathrm{min}$ heating rate and cooling to $800{ }^{\circ} \mathrm{C}$ for two-cyclic redox reactions.

Table 3. The oxygen uptake and release ratio metallic oxides during redox reaction.

\begin{tabular}{|c|c|c|c|c|c|c|}
\hline \multirow{2}{*}{ Materials } & \multicolumn{2}{|c|}{$\mathrm{O}_{2}$ Released $(\mu \mathrm{mol} / \mathrm{g})$} & \multicolumn{2}{|c|}{$\mathrm{O}_{2}$ Uptake $(\mu \mathrm{mol} / \mathrm{g})$} & \multicolumn{2}{|c|}{$\mathrm{O}_{2}$ Uptake/O $\mathrm{O}_{2}$ Released Ratio } \\
\hline & 1st Cycle & 2nd Cycle & 1st Cycle & 2nd Cycle & 1st Cycle & 2nd Cycle \\
\hline 25 wt. $\%$ Mno + 75 wt. $\%$ CoO & 2125 & 1625 & 1625 & 1563 & 0.760 & 0.960 \\
\hline 50 wt. $\%$ Mno + 50 wt. $\%$ CoO & 2250 & 1843 & 1875 & 1819 & 0.830 & 0.990 \\
\hline 75 wt. $\%$ Mno + 50 wt. $\%$ CoO & 3972 & 1569 & 1650 & 1561 & 0.420 & 0.996 \\
\hline 100 wt. $\% \mathrm{CoO}$ & 2032 & 1413 & 1475 & 1238 & 0.730 & 0.880 \\
\hline 100 wt. $\% \mathrm{Fe}_{3} \mathrm{O}_{4}$ & 516 & 1066 & 1097 & 1063 & 2.100 & 0.997 \\
\hline 100 wt. \% Mno & 1372 & 391 & 469 & 375 & 0.340 & 0.960 \\
\hline
\end{tabular}

\subsection{The Impact of Gas Flow Rate on the Redox Reaction}

From Table 4 the (Fe,Co,Mn)Ox material was tested for different $\mathrm{Ar}$ and $\mathrm{O}_{2}$ flow rates during the heating-cooling processes of the redox reaction. Consequently, $30 \mathrm{~mL}$ Ar-20 $\mathrm{mL} \mathrm{O}_{2} / \mathrm{min}$ gas flow rate was appropriate for stable and high oxygen uptake. Figure $5 \mathrm{a}$ shows the impacts of applied the different combined argon and oxygen gases flow rate on $(\mathrm{Fe}, \mathrm{Co}, \mathrm{Mn}) \mathrm{Ox}$. From that Figure $5 \mathrm{a}$, it was observed that the cyclic reduction reaction elicited by $30 \mathrm{~mL} \mathrm{Ar}-20 \mathrm{~mL} \mathrm{O} / \mathrm{min}$ gas flow rate had great contributions to oxygen uptake. Figure $5 \mathrm{~b}$ shows the influence of $\mathrm{Ar}$ and $\mathrm{O}_{2}$ flow rates on redox reaction kinetics. From that figure, it was revealed that keeping Ar gas flow rate constant and altering the oxygen flow resulted in constant $\mathrm{O}_{2}$ uptake in cycle 1 and slightly constant uptake in cycle 2 . Figure $5 c$ shows the DSC analysis of $(\mathrm{Fe}, \mathrm{Co}, \mathrm{Mn}) \mathrm{Ox}$ redox with time and the endothermic-exothermic thermal process along with phase change of temperature at $30 \mathrm{~mL} \mathrm{Ar} / \mathrm{min}-20 \mathrm{~mL} \mathrm{O} 2 / \mathrm{min}$ gas flow rate. Figure $5 \mathrm{~d}$ shows the weight loss during redox reaction for different values $\mathrm{Ar}$ and $\mathrm{O}_{2}$ flow rates during the charging step. From Figure $5 \mathrm{~d}$, the $30 \mathrm{~mL} \mathrm{Ar}-20 \mathrm{~mL} \mathrm{O} / \mathrm{min}$ 
combined gas flow rates on ( $\mathrm{Fe}, \mathrm{Co}, \mathrm{Mn}) \mathrm{Ox}$ increased weight loss when compared with other combined gas flow rates. Figure $5 \mathrm{e}$ shows the weight loss for four types of combined Ar- $\mathrm{O}_{2}$ flow rates for both cycles. Figure $5 \mathrm{f}$ shows the heat flow curve with the charging temperature. From Figure 5 e,f, it was revealed that $30 \mathrm{~mL} \mathrm{Ar}-20 \mathrm{~mL} \mathrm{O} / 2 \mathrm{~min}$ gas flow rate depicted stable redox reaction for the $(\mathrm{Fe}, \mathrm{Co}, \mathrm{Mn}) \mathrm{Ox}$ material.

Table 4. Gas flow rate and $\mathrm{O}_{2}$ storage capacity.

\begin{tabular}{|c|c|c|c|c|c|c|}
\hline \multirow{2}{*}{$\begin{array}{c}\text { Materials } \\
\text { Argon and } \mathrm{O}_{2} \text { Flow }\end{array}$} & \multicolumn{2}{|c|}{$\mathrm{O}_{2}$ RELEASED $(\mu \mathrm{mol} / \mathrm{g})$} & \multicolumn{2}{|c|}{$\mathrm{O}_{2}$ Uptake $(\mu \mathrm{mol} / \mathrm{g})$} & \multicolumn{2}{|c|}{$\mathrm{O}_{2}$ Uptake $/ \mathrm{O}_{2}$ Released Ratio } \\
\hline & 1st Cycle & 2nd Cycle & 1st Cycle & 2nd Cycle & 1st Cycle & 2nd Cycle \\
\hline $20-20$ & 1017 & 338 & 188 & 159 & 18.440 & 47.200 \\
\hline $30-20$ & 1097 & 388 & 404 & 327 & 36.810 & 84.270 \\
\hline $30-30$ & 1159 & 393 & 293 & 187 & 25.350 & 47.690 \\
\hline $30-50$ & 1129 & 463 & 314 & 243 & 27.810 & 54.465 \\
\hline
\end{tabular}

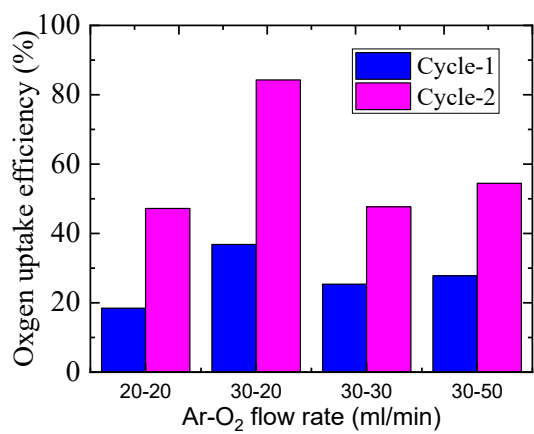

(a)

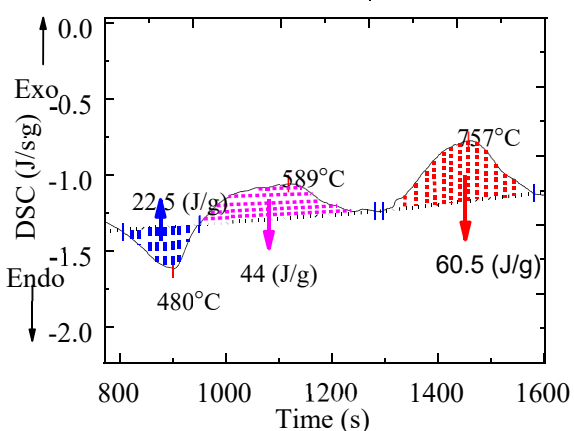

(c)

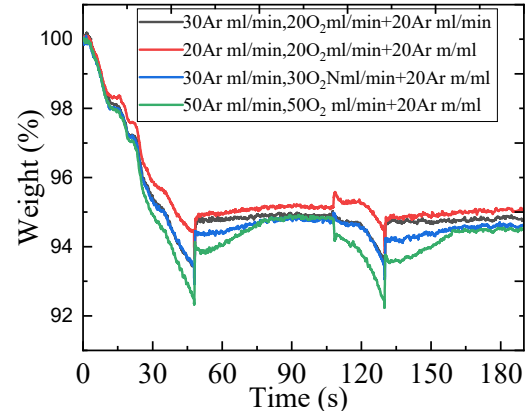

(e)

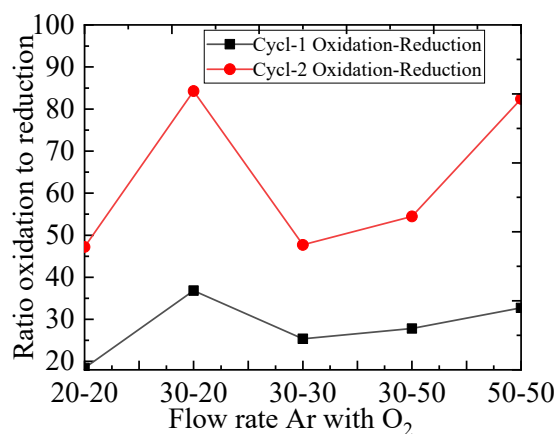

(b)

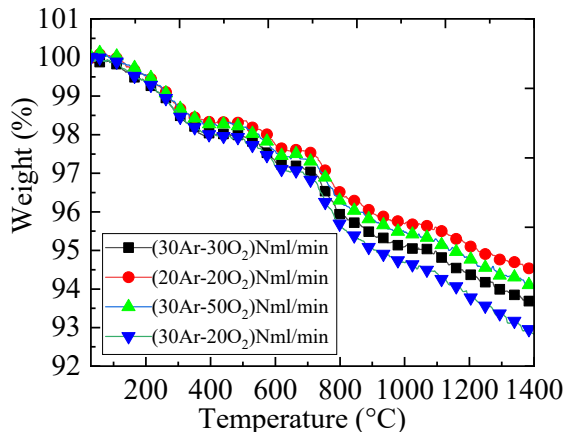

(d)

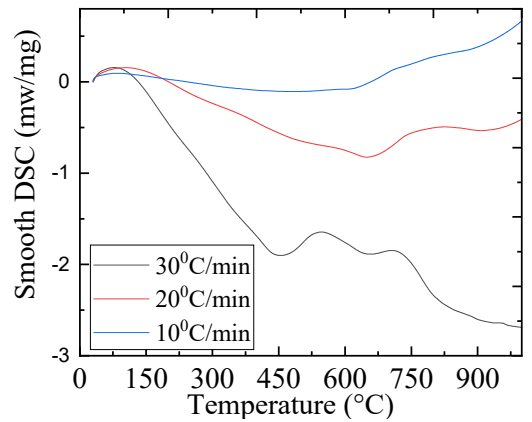

(f)

Figure 5. The impacts of different $\mathrm{Ar}$ and $\mathrm{O}_{2}$ combined flow rates on the redox reaction for the $(\mathrm{Fe}, \mathrm{Co}, \mathrm{Mn}) \mathrm{Ox}$ : (a) $\mathrm{O}_{2}$ uptake efficiency with $\mathrm{Ar}-\mathrm{O}_{2}$ flow rates; (b) impact of gas flow rates on redox reaction; (c) DSC analysis with phase change temperature picks and enthalpies; (d) the impact of gas flow rates on weight loss during heating in the first cycle, and (e) the weight loss with time for both cyclic redox reactions including the impacts additional $20 \mathrm{~mL} / \mathrm{min}$ Ar protective gas; (f) smooth DSC analysis in terms of heat flow curve against the variation in charging temperature. 


\subsection{The Effect of Heating Rate on Redox Reaction}

Heating rate is one of the determinant factors that affect the redox reaction of metallic oxides. Figure 6a shows the smooth DSC analysis of the effect of different heating rates on the $(\mathrm{Fe}, \mathrm{Co}, \mathrm{Mn}) \mathrm{Ox}$ material as a function of time. As observed from Figure 6a, during the charging process, heating rate at $30^{\circ} \mathrm{C} / \mathrm{min}$ that was applied during redox shifts to negative than other heating rates at the time of $87 \mathrm{~min}$ and the flow heat increase sharply at $100 \mathrm{~min}$. The redox reaction rate at $10^{\circ} \mathrm{C} / \mathrm{min}$ dominated that of $20^{\circ} \mathrm{C} / \mathrm{min}$ for about $143 \mathrm{~min}$. However, from 143 to $243 \mathrm{~min}$ reaction time, the redox reaction at $20^{\circ} \mathrm{C} / \mathrm{min}$ dominated that of $10^{\circ} \mathrm{C} / \mathrm{min}$ heating rate. From 243 to 300 min reaction time, redox reaction at $20^{\circ} \mathrm{C} / \mathrm{min}$ heating rate was lower than that of $10^{\circ} \mathrm{C} / \mathrm{min}$ heating rate. Since $30^{\circ} \mathrm{C} / \mathrm{min}$ heating rate has impacted the TGA machine, there had been additional $20 \mathrm{~mL} / \mathrm{min}$ argon flow during charging at $1400{ }^{\circ} \mathrm{C}$ and discharging at $800{ }^{\circ} \mathrm{C}$. However, the addition of Ar gas affected the decomposition rate of the $(\mathrm{Fe}, \mathrm{Co}, \mathrm{Mn}) \mathrm{Ox}$ material, as it shifted the enthalpy to the negative region as shown in Figure $6 \mathrm{~b}$. From Figure $6 \mathrm{~b}$, comparing the heat flow rates $\left(10,20,30^{\circ} \mathrm{C} / \mathrm{min}\right)$ at $951^{\circ} \mathrm{C}$, the $(\mathrm{Fe}, \mathrm{Co}, \mathrm{Mn}) \mathrm{Ox}$ material had $1.6 \mathrm{~kJ} / \mathrm{g},-0.99 \mathrm{~kJ} / \mathrm{g}$, and $-4.65 \mathrm{~kJ} / \mathrm{g}$, respectively. From 400 to $1400{ }^{\circ} \mathrm{C}$ during charging, the $20^{\circ} \mathrm{C} / \mathrm{min}$ heating rate affected the metallic oxides smoothly and without altering enthalpy, whereas $10^{\circ} \mathrm{C} / \mathrm{min}$ heating rate diverged to the highly positive enthalpy region and $30^{\circ} \mathrm{C} / \mathrm{min}$ rating diverged to the highly negative enthalpy region. Figure $5 \mathrm{c}$ shows the derivative weight during the charging process from 30 to $1400^{\circ} \mathrm{C}$. From that Figure $5 \mathrm{c}$, the phase change indicator temperature is shown on the critical curves for the different values of heating rates. For $30^{\circ} \mathrm{C} / \mathrm{min}$ heating rate case, the phase change values temperature for the redox were 261,778 , and $1160^{\circ} \mathrm{C}$; at $20^{\circ} \mathrm{C} / \mathrm{min}$ heating rate the values were 371 , 822 , and $1112{ }^{\circ} \mathrm{C}$, and at $10^{\circ} \mathrm{C} / \mathrm{min}$ heating rate for the values were 324,800 , and $1077^{\circ} \mathrm{C}$. Thus, the phase change temperature values for the metallic oxides subjected to $20^{\circ} \mathrm{C} / \mathrm{min}$ heating rate were generally higher than those at $10{ }^{\circ} \mathrm{C} / \mathrm{min}$ heating rate. In the early stage of the redox reaction, the onset temperature corresponded to heating rate in the order $30<10<20^{\circ} \mathrm{C} / \mathrm{min}$. Figure 5e shows the weight loss with corresponding charging temperature-axis and it revealed that decomposition reaction at $30^{\circ} \mathrm{C} / \mathrm{min}$ heating rate was higher than those of $10^{\circ} \mathrm{C} / \mathrm{min}$ and $20^{\circ} \mathrm{C} /$ min heating rates. Figure $6 \mathrm{~d}$ shows the weight loss with corresponding charging temperature-axis and it revealed that decomposition reaction at $30^{\circ} \mathrm{C} / \mathrm{min}$ heating rate was higher than those of $10^{\circ} \mathrm{C} / \mathrm{min}$ and $20^{\circ} \mathrm{C} / \mathrm{min}$ heating rates. Figure $6 \mathrm{e}$ shows the conversion rate for the $(\mathrm{Fe}, \mathrm{Co}, \mathrm{Mn}) \mathrm{Ox}$ material at different heating rates. It revealed that increase in temperature at $30{ }^{\circ} \mathrm{C} / \mathrm{min}$ heating rate attained a conversion rate of 1.25 at $964{ }^{\circ} \mathrm{C}$, which sharply decreased to 1 at $1029^{\circ} \mathrm{C}$. Figure $6 \mathrm{f}$ shows the conversion rate the whole redox reaction process. It revealed that conversion rate increased sharply for about $91 \mathrm{~min}$ of the redox process started, and sharply decreased when it reached at $100 \mathrm{~min}$ then became constant until to $236 \mathrm{~min}$, increased at $258 \mathrm{~min}$ and decreased at $266 \mathrm{~min}$ and then became constant afterwards. It was also be deducted from that figure that the conversion rates during $10^{\circ} \mathrm{C} / \mathrm{min}$ and $20^{\circ} \mathrm{C} / \mathrm{min}$ heating rates overlapped except between 206 to $208 \mathrm{~min}$. The conversation rate during $10^{\circ} \mathrm{C} / \mathrm{min}$ heating rate was higher than that during $20^{\circ} \mathrm{C} / \mathrm{min}$ heating rate. In addition, from 287 to $320 \mathrm{~min}$, the conversion rate during $20^{\circ} \mathrm{C} / \mathrm{min}$ heating rate was higher than that during $10^{\circ} \mathrm{C} / \mathrm{min}$ heating rate. 


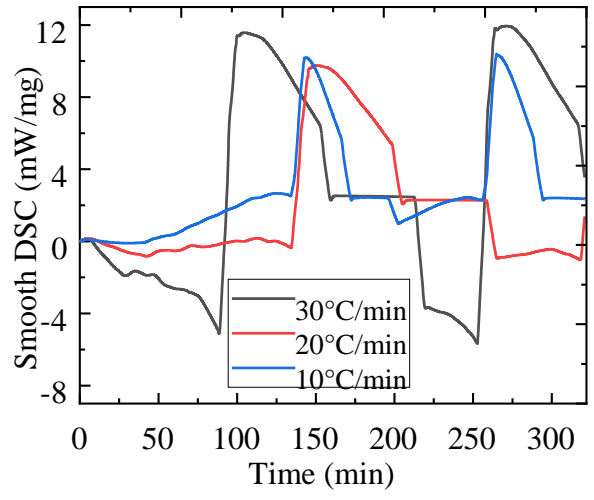

(a)

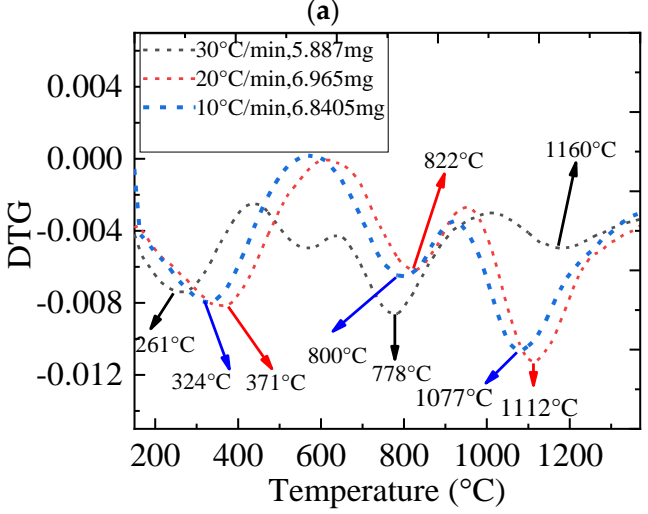

(c)

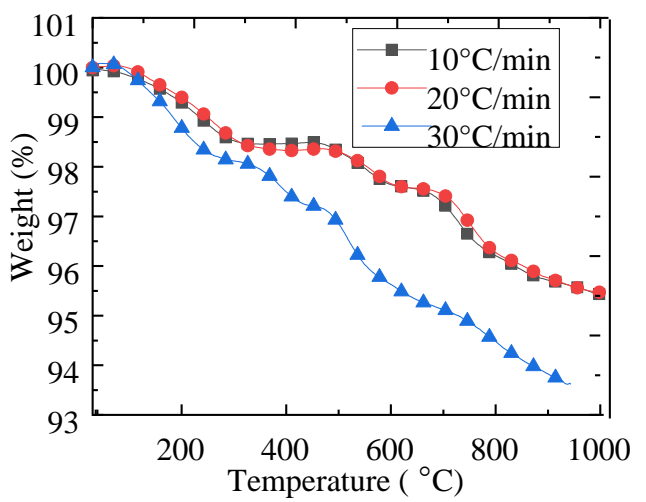

(e)

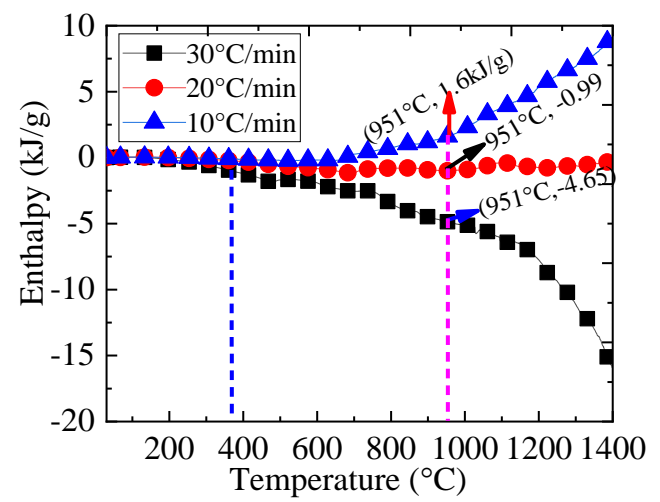

(b)

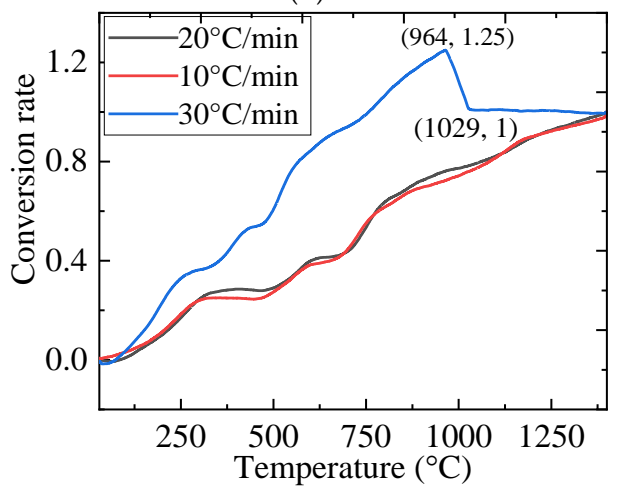

(d)

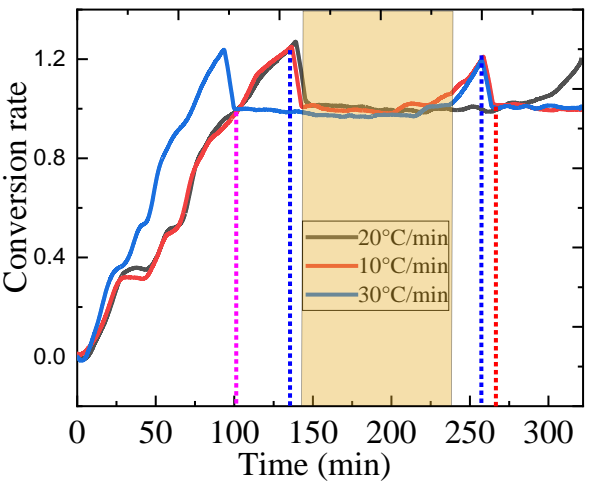

(f)

Figure 6. The impact of heat flow rate during redox reactions: (a) Changes in smooth DSC with time; (b) changes in enthalpy with charging temperature in cycle $1 ;$ (c) phase change indicator graph during cycle 1 ; (d) changes in conversion rate with charging temperature in cycle 1 ; (e) changes in TGA with charging temperature in cycle 1 and (f) changes in conversion rate during the whole charging-discharging time for both redox cycles.

\subsection{The EDS and SEM analysis of the (Fe,Co,Mn)Ox Material EDS of the (Fe,Co,Mn)Ox Material}

Figure 7a shows the EDS spectrum of the reduced elements of $\mathrm{O}, \mathrm{Mn}, \mathrm{Fe}$, and $\mathrm{Co}$ with weight percentages of $41.78 \%, 10.14 \%, 38.23 \%$, and $9.84 \%$ and element compositions of $71.59 \%, 5.06 \%, 18.77 \%$, and $4.58 \%$, respectively. Excluding impurities and oxygen, Figure $7 \mathrm{~b}$ shows the reduced EDS spectrum of $\mathrm{Mn}, \mathrm{Fe}$, and Co with weight percentages $17.36 \%, 65.57 \%$, and $17.06 \%$ element compositions of $17.76 \%, 65.97 \%$, and $16.27 \%$, respectively. Figure 7c shows the EDS mapping images of the reduced (Fe,Co,Mn)Ox oxide and Figure 7d-g show the EDS mapping pictures of $\mathrm{O}, \mathrm{Mn}, \mathrm{Fe}$, and Co. From the EDS mapping images, there were black spots seen on the surface of the material, which was created due to the interaction of the applied field and missing the electrons atoms of that element. During 
the redox reaction with applied temperature at thermal charging step of $30{ }^{\circ} \mathrm{C}$ to $1400{ }^{\circ} \mathrm{C}$, the added weight was 100 wt. $\% \mathrm{Fe}_{3} \mathrm{O}_{4}$ on 50 wt. $\% \mathrm{MnO}+50 \mathrm{wt}$ \% $\mathrm{CoO}$. However, from the EDS weight analysis spectrum distribution, the untreated weight percentage of $\mathrm{Fe}-\mathrm{O}$ $(38.28 \%)$ was higher than the sum of the weight percentage of $\mathrm{Co}-\mathrm{O}$ and $\mathrm{Mn}-\mathrm{O}(10.14 \%+$ $9.84 \%)$ and the treated weight percentage of Fe $(65.57 \%)$ and Mn-Co $(17.36 \%+17.06 \%)$. From the TGA analysis in Sections 3.1 and 3.2, it was deduced that the reduction of $\mathrm{CoO}$ and $\mathrm{MnO}$ was faster than $\mathrm{Fe}_{3} \mathrm{O}_{4}$. Furthermore, Fe-O was not well reduced except for the $0.31 \%$ weight loss due to dehydration until it reached $1200{ }^{\circ} \mathrm{C}$. Nevertheless, at $1200{ }^{\circ} \mathrm{C}$, Fe-O was reduced by $1.31 \%$ from its initial weight as compared to a maximum reduction of $\mathrm{MnO}(9.18 \%)$ and $\mathrm{CoO}(6.27 \%)$. This might be due to the availability of $65 \%$ of Fe-O during redox and that half of its weight was $\mathrm{Mn}-\mathrm{Co}$, which was because the redox reaction decreased the weight of Mn-Co more than that of the Fe-O. However, the EDS spectrum and mapping results both revealed the uniform distribution of composed elements in the reduced reaction. Figure 8 shows the EDS spectrum and mapping analysis of the fresh (Fe, $\mathrm{Co}, \mathrm{Mn}) \mathrm{Ox}$ material. It was revealed that the percentage of weight distribution spectrum of $\mathrm{Fe}, \mathrm{Mn}$, and Co were 24.04, 3.3, and 72.67, and weight percentage of atomic weight composition were $24.37 \%, 72.5 \%$, and $3.12 \%$, respectively. Figure 8 b shows the electronic image of the fresh $(\mathrm{Fe}, \mathrm{Co}, \mathrm{Mn}) \mathrm{Ox}$ mixture before the reduction process. Figure $8 \mathrm{c}-\mathrm{f}$ show the EDS mapping images of the fresh $\mathrm{Fe}, \mathrm{O}, \mathrm{Mn}$, and Co. Unlike the reduced EDS spectrum weight analysis in Figure 7a, the EDS spectrum observation in Figure 8a particularly for Co, had less percentage weight distribution and it had an uneven weight distribution when observed over the EDS mapping image in Figure 8c. From Figure 8c, Fe had more evenly distributed weights and Mn was less evenly distributed. However, Co had uneven, less weight, and scattered form of weight distribution and white-colored spots scattered on the surface of the EDS maps indicate the presence of Co and Mn, while the black points spots indicate the existence of oxygen.

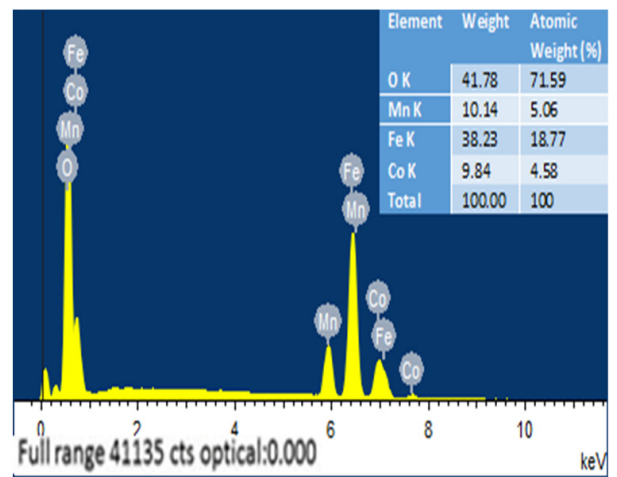

(a)

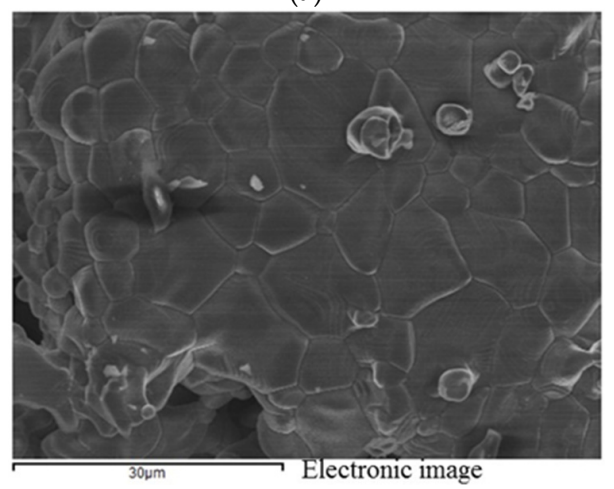

(c)

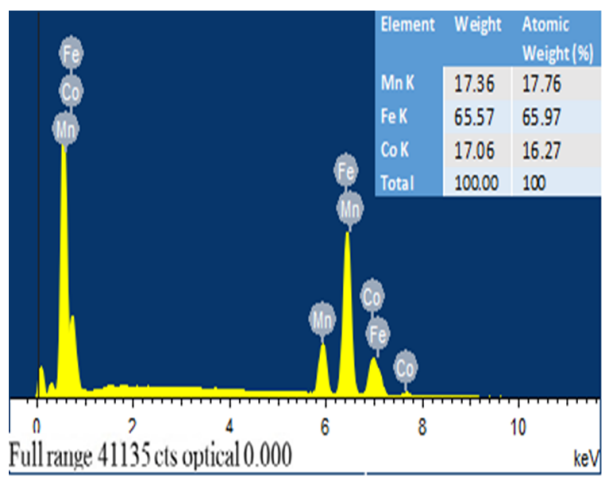

(b)

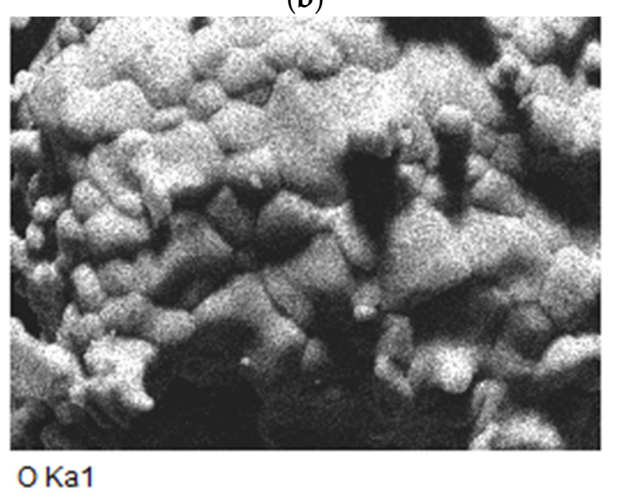

(d)

Figure 7. Cont. 


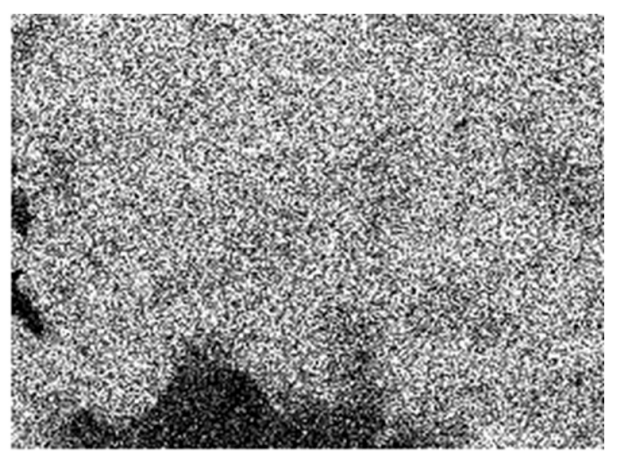

Mn Ka1

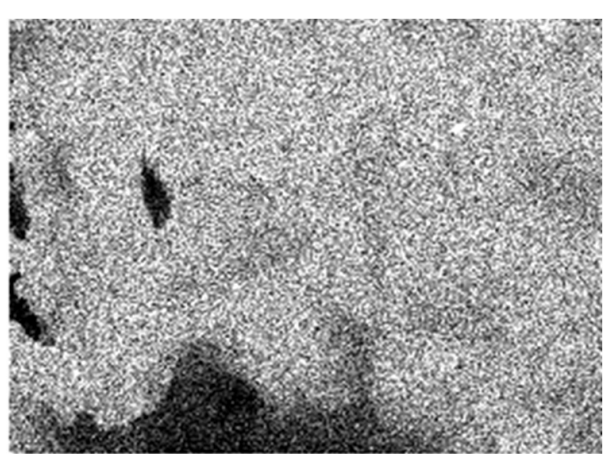

Fe Ka1

(e)

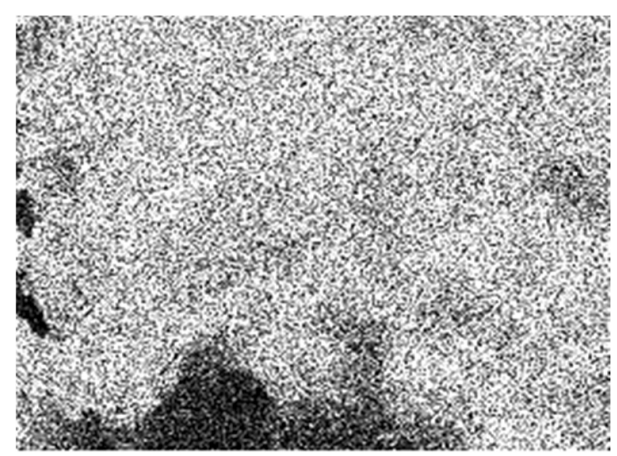

(f)

(g)

Figure 7. EDS analysis of reduced (Fe,Co,Mn)Ox: (a) EDS spectrum; (b) the treated and reduced spectrum, (c) electronic image of the (Fe,Co,Mn)Ox material; (c) EDS mapping picture of $\mathrm{Fe}, \mathrm{Mn}, \mathrm{Co}$, and $\mathrm{O}$; (d) EDS mapping of O; (e) EDS mapping of Mn; (f) EDS mapping of Fe; (g) EDS mapping of Co.

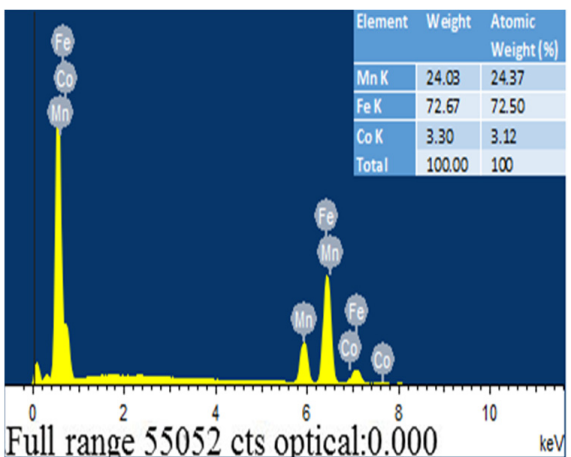

(a)

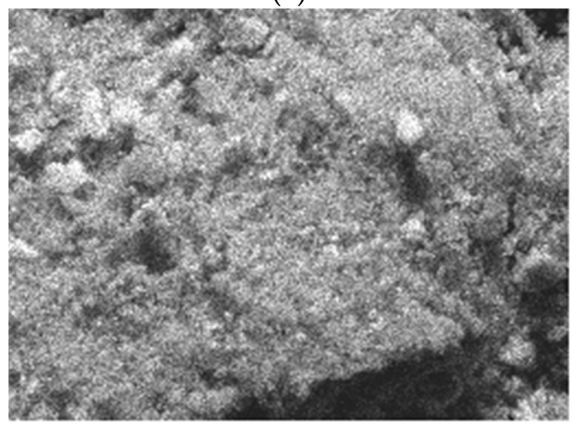

O Ka1

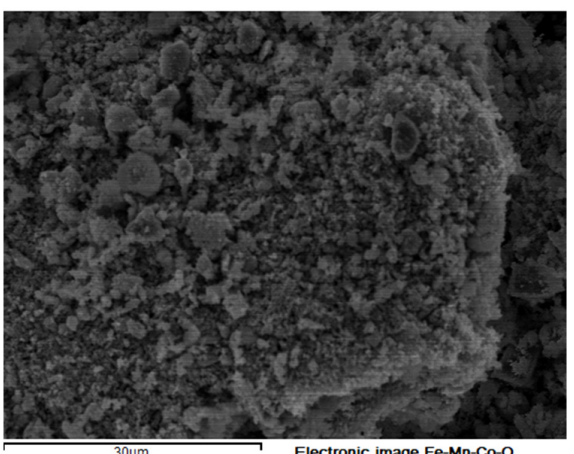

(b)

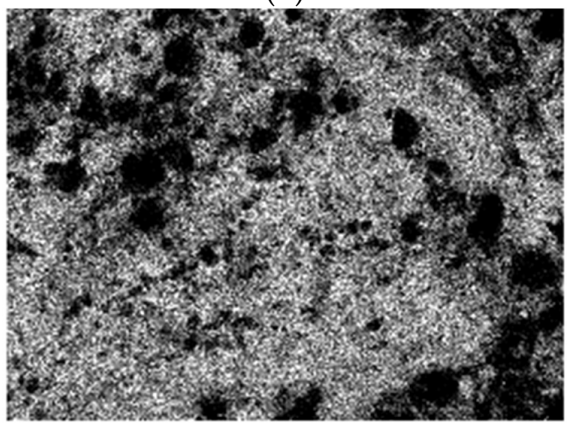

Fe Ka1

(c)

(d)

Figure 8. Cont. 


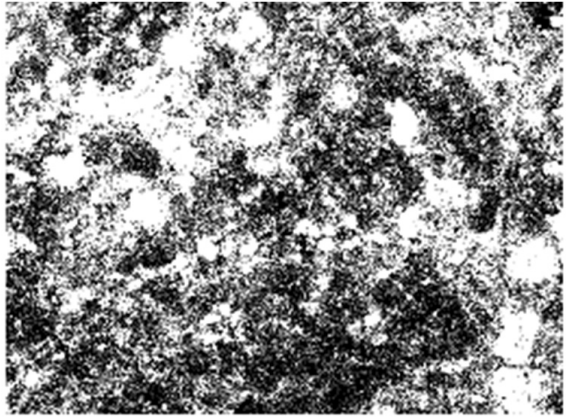

Mn Ka1

(e)

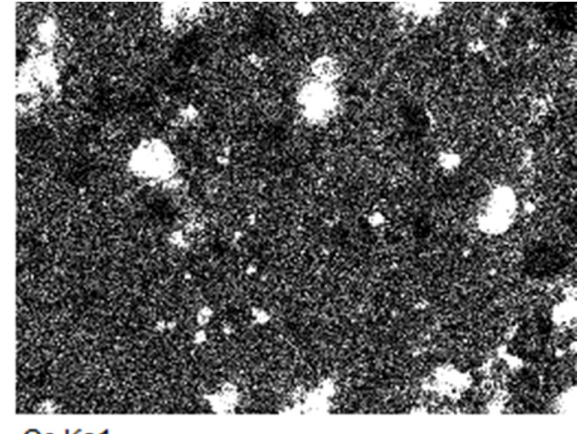

(f)

Figure 8. EDS analysis the fresh (Fe,Co,Mn)Ox material: (a) EDS spectrum; (b) electronic image of the (Fe,Co,Mn)Ox material; (c) EDS mapping of O; (d) EDS mapping of Fe; (e) EDS mapping of Mn; (f) EDS mapping of Co.

\subsection{The SEM Analysis}

The SEM images of the (Fe, Co,Mn)Ox are shown in Figures 9 and 10. Figure 9 shows the morphology of $(\mathrm{Fe}, \mathrm{Co}, \mathrm{Mn}) \mathrm{Ox}$ material after the two-cycle reaction process. The (Fe,Co,Mn)Ox catalyst was air-dried and then characterized. The (Fe,Co,Mn)Ox material was composed of highly agglomerated polygonal-shaped structures, which had highly rough surfaces (cracked and weathered sections). Figure $9 a-d$ deprive rough surface features, which comprised small and large crystal-like structures that coincided with the EDS spectrum results, suggesting that the small structures belong to cobalt and manganese fragments while the large structures were iron fragments. Figure $10 \mathrm{a}-\mathrm{d}$ shows the morphology of (Fe,Co,Mn)Ox material after the two-cycle redox reaction for different applied voltage and dimensions. Figure $10 \mathrm{a}-\mathrm{d}$ also revealed large structures with smoother surfaces and less agglomerated structures. Figure 10c shows hexagonal shape whereas Figure $10 \mathrm{~d}$ shows a porous structure, which is important for energy storage application.

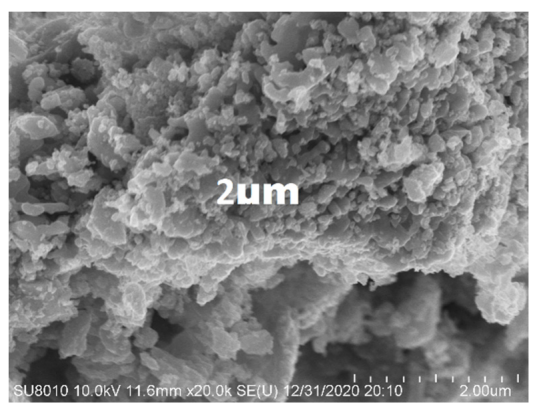

(a)

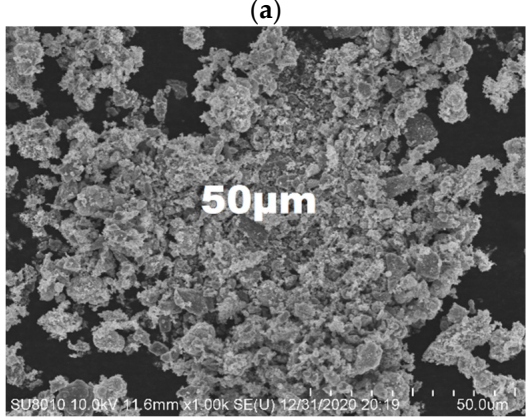

(c)

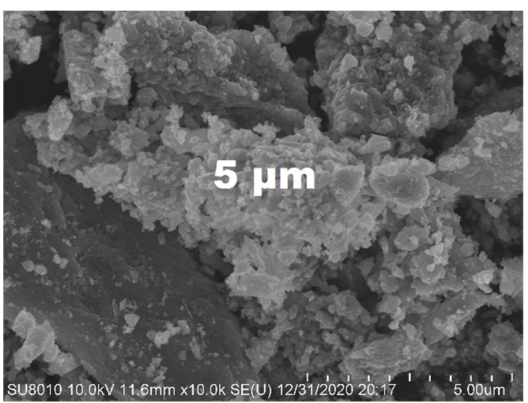

(b)

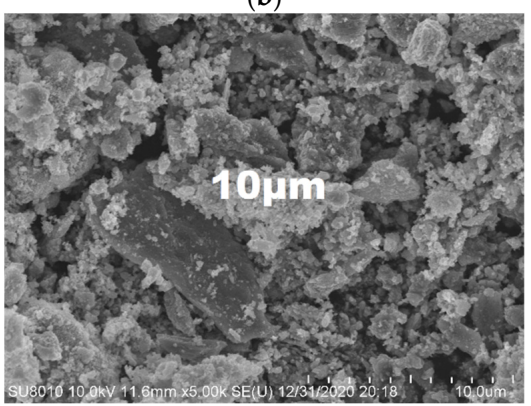

(d)

Figure 9. SEM micrographs of the (Fe,Co,Mn)Ox material. (a) Image acquired using a $10 \mathrm{kv}$ accelerating voltage at $20,000 \times$ length of $2 \mu \mathrm{m}$; (b) image acquired using a $10 \mathrm{kv}$ accelerating voltage at $10,000 \times$ length of $5 \mu \mathrm{m}$; (c) image acquired using a $10 \mathrm{kv}$ accelerating voltage at $1000 \times$ length of $50 \mu \mathrm{m}$ and (d) image acquired a $10 \mathrm{kv}$ accelerating voltage at $5000 \times$ length of $10 \mu \mathrm{m}$. 


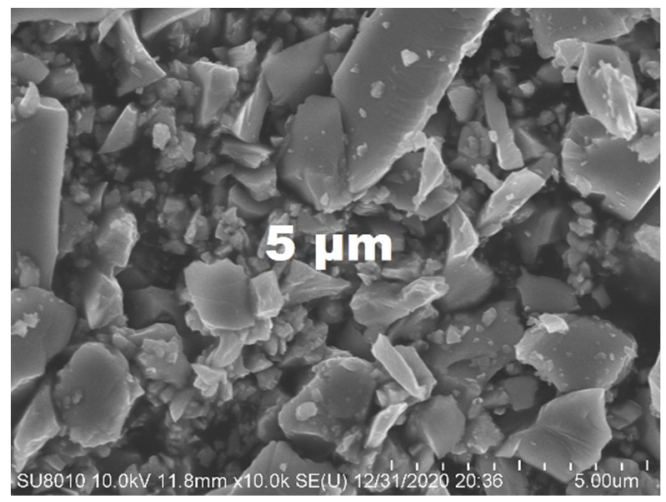

(a)

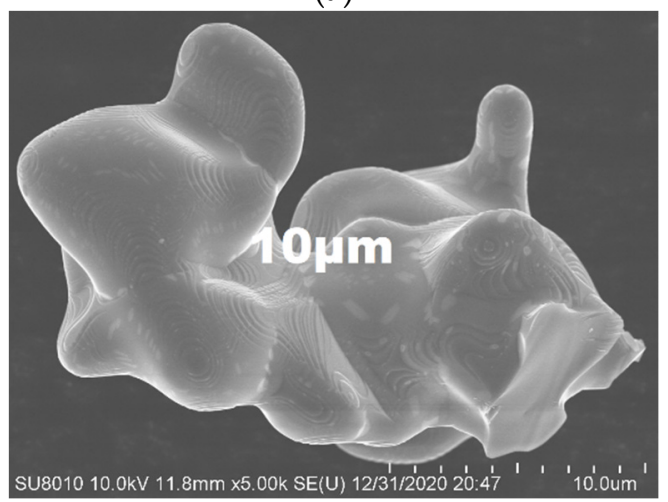

(c)

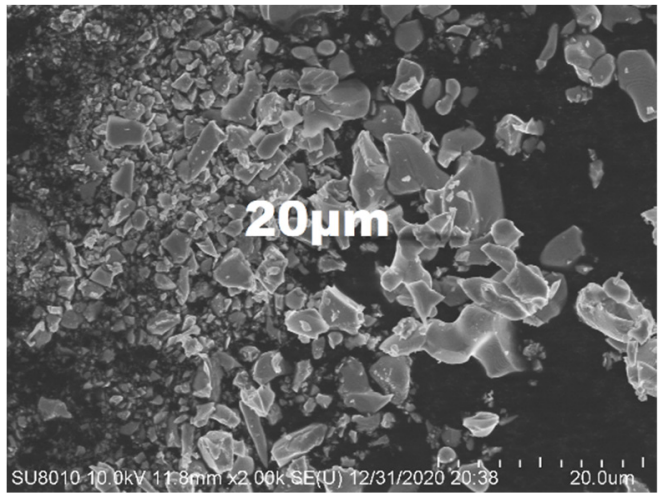

(b)

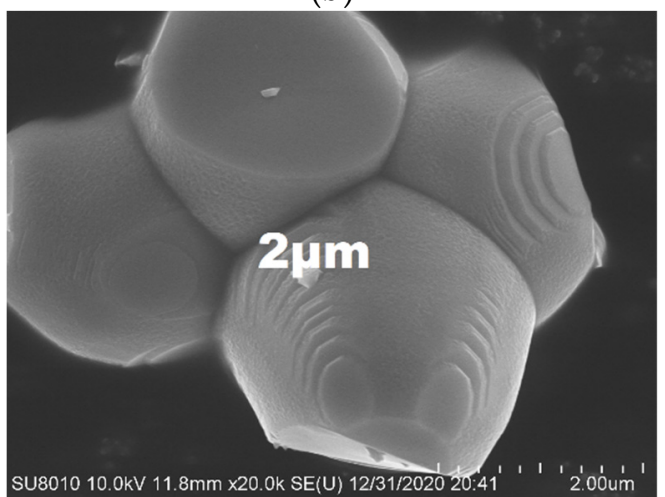

(d)

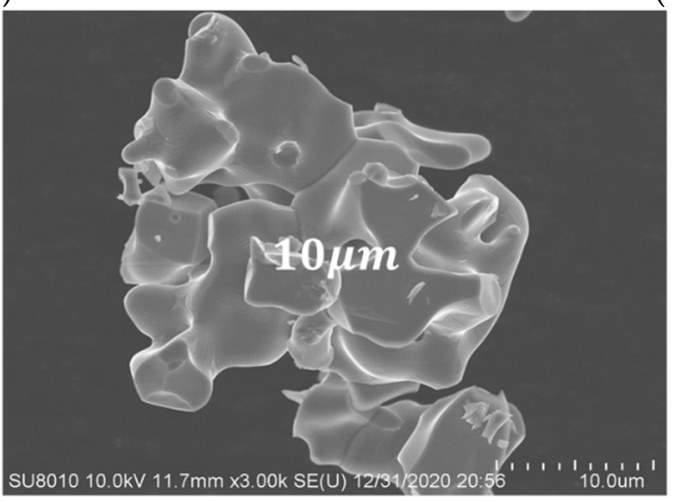

(e)

Figure 10. SEM micrographs of the treated (Fe,Co,Mn)Ox material: (a) Image acquired using a $10 \mathrm{kv}$ accelerating voltage at $10,000 \times$ length of $5 \mu \mathrm{m} ;(\mathbf{b})$ image acquired using a $10 \mathrm{kv}$ accelerating voltage at $2000 \times$ length of $20 \mu \mathrm{m}$; (c) image acquired using a $10 \mathrm{kv}$ accelerating voltage at $5000 \times$ length of $10 \mu \mathrm{m}$; (d) image acquired using a $10 \mathrm{kv}$ accelerating voltage at $20,000 \times$ length of $2 \mu \mathrm{m}$, and (e) image acquired using a $10 \mathrm{kv}$ accelerating voltage at $3000 \times$ length of $10 \mu \mathrm{m}$.

\section{Material and Methods}

\subsection{Material Synthesis and Characterization}

Pure oxides namely $\mathrm{CoO}, \mathrm{MnO}, \mathrm{Fe}_{3} \mathrm{O}_{4}$, and mixed oxides with proportion of 25 wt.\% $\mathrm{CoO}+75$ wt. $\% \mathrm{MnO}, 50$ wt. $\% \mathrm{CoO}+50$ wt. $\% \mathrm{MnO}$, and 75 wt. $\% \mathrm{CoO}+25$ wt. $\% \mathrm{MnO}$ were synthesized. The proportion was taken by weight. First, $30 \mathrm{mg}$ each of the six metallic oxides was prepared, it is, $30 \mathrm{mg}$ of $\mathrm{CoO}, 30 \mathrm{mg}$ of $\mathrm{MnO}, 30 \mathrm{mg}$ of $\mathrm{Fe}_{3} \mathrm{O}_{4}, 7.5 \mathrm{mg}$ of $\mathrm{CoO}$ $+22.5 \mathrm{mg}$ of $\mathrm{MnO}$ (31.7), $15 \mathrm{mg}$ of $\mathrm{CoO}+15 \mathrm{mg}$ of $\mathrm{MnO}$ and $22.5 \mathrm{mg}$ of $\mathrm{CoO}+7.5 \mathrm{mg}$ of $\mathrm{MnO} .42 .3 \mathrm{~mol} \%$ of $\mathrm{MnO}, 40 \mathrm{~mol} \%$ of $\mathrm{CoO}, 12.8 \mathrm{~mol} \%$ of $\mathrm{Fe}_{3} \mathrm{O}_{4}, 10.6 \mathrm{~mol} \%$ of $\mathrm{MnO}+$ $30 \mathrm{~mol} \%$ of $\mathrm{CoO}, 10 \mathrm{~mol} \%$ of $\mathrm{CoO}+31.7 \mathrm{~mol} \%$ of $\mathrm{MnO}$ and $20 \mathrm{~mol} \%$ of $\mathrm{CoO}+21 \mathrm{~mol} \%$ of $\mathrm{MnO}$. The purity of metallic oxide was $99.99 \%$. The powders were heated at a range of 30 to $1400{ }^{\circ} \mathrm{C}$ for about $180 \mathrm{~min}$. 


\subsection{Experimental Procedure for Thermochemical Redox Cycling}

The experimental result data were collected and analyzed using transition temperature during reduction-oxidation process and the, oxygen uptake capacity, oxygen release and reaction enthalpies were obtained by using TGA and DSC analysis. The different metallic oxide samples were exposed to the test of TGA and DSC, EDS and SEM analysis.

The redox reaction cycles were performed in $\mathrm{O}_{2} / \mathrm{Ar}$ atmosphere $(30 \mathrm{~mL} / \mathrm{min} \mathrm{Ar}$ and $20 \mathrm{~mL} / \mathrm{min} \mathrm{O}_{2}$ ), between 30 to $1400{ }^{\circ} \mathrm{C}$ for each metallic oxide. In the reduction-oxidation steps, the heating rate was $30^{\circ} \mathrm{C} / \mathrm{min}$ and the cooling step was $20^{\circ} \mathrm{C} / \mathrm{min}$ for the reoxidation. The charging and discharging processes for all materials were performed in two series cycles. The metallic oxides were heated from 30 to $1400{ }^{\circ} \mathrm{C}$ at a heating rate of $30{ }^{\circ} \mathrm{C} / \mathrm{min}$ (charging), cooled from 1400 to $800{ }^{\circ} \mathrm{C}$ at $20^{\circ} \mathrm{C} / \mathrm{min}$ heating rate (discharging) then heated to $1400{ }^{\circ} \mathrm{C}$ (charging) and held at that temperature for 2 min followed by cooling to $800^{\circ} \mathrm{C}$ and held at that temperature for $30 \mathrm{~min}$ and then heated from 800 to $1400{ }^{\circ} \mathrm{C}$ at $30^{\circ} \mathrm{C} / \mathrm{min}$ (charging) and held at that temperature for $2 \mathrm{~min}$ and then cooled to $800{ }^{\circ} \mathrm{C}$ at $20^{\circ} \mathrm{C} / \mathrm{min}$ (discharging). These processes were conducted for achieving stability as well as to analyze the oxygen uptake and release of oxygen, weight loss, and phase changing temperature in the redox reactions.

\subsection{Thermodynamic Calculations}

The metallic oxides experimental data were analyzed using OriginPro software (2018a, Northampton, MA, USA). For the calculations, using the OriginPro software and extracted data from the TGA and DSC excel, the oxygen uptake, oxygen release, the weight loss, the onset reduction temperatures, the conversion rate, the phase change temperatures, the gas flow rates, and the heat rate, which were applied during redox reactions, were analyzed and calculated. During the experiment, the additional argon gas for protection were considered. The gaseous components, $\mathrm{O}_{2}$, and Ar were considered, with ideal mixing properties. The total pressure was always $1 \mathrm{~atm}$. The phase change diagrams and phase changing temperatures were plotted and calculated. The calculations provide the theoretical mass loss (i.e., oxygen storage capacity) and rate of conversion of metallic oxides in the trial of the tests, which were calculated as follows. From

$$
\begin{gathered}
\eta=\left(\frac{\Delta \mathrm{w}(\%)}{32}\right) \times 10,000 \mu \mathrm{mol} / \mathrm{g} \\
\chi=\left(\frac{\mathrm{m}_{\mathrm{o}}-\mathrm{m}(\mathrm{T})}{\mathrm{m}_{\mathrm{o}}-\mathrm{m}_{\infty}}\right) \\
\chi_{\text {con }}=\left(\frac{\mathrm{w}_{\text {in }}(\mathrm{mols})-\mathrm{w}_{\mathrm{O}_{2}}(\text { mols })}{\mathrm{w}_{\text {in }}(\mathrm{mols})+\mathrm{w}_{\mathrm{O}_{2}}(\mathrm{mols})}\right)
\end{gathered}
$$

From the non-parametric kinetics (NPK), which originally was developed by Serrra et al. [56-58] where, $\eta$ is the $\mathrm{O}_{2}$ storage or release capacity, $\Delta(\mathrm{w} \%)$ is the weight loss, $\chi$ is the conversion rate, $\mathrm{m}_{\mathrm{o}}$ is initial weight, $\mathrm{m}(\mathrm{T})$ is the weight at temperature $(\mathrm{T}), \mathrm{m}_{\infty}$ the residue weight at the end of reaction, $\chi_{\text {con }}$ is conversion efficiency, $\mathrm{w}_{\text {in }}$ is the weight of metallic oxides set for redox, $\mathrm{w}_{\mathrm{O}_{2}}$ is the weight of metallic oxides changes to oxygen.

\section{Conclusions}

This study utilized different proportions of $\mathrm{MnO}, \mathrm{CoO}$, and $\mathrm{Fe}_{3} \mathrm{O}_{4}$ to produce a metallic oxide material with high thermal storage performance using a two-cycle redox reaction. Proper moisture of $\mathrm{MnO}$ and $\mathrm{CoO}$ can stabilize the weak reaction rate of $\mathrm{Mn}$ and fast reaction of $\mathrm{CoO}$ as well as enhance cyclic stability and oxygen uptake ratio. The combination of $50 \mathrm{wt} . \% \mathrm{MnO}+50 \mathrm{wt} . \% \mathrm{CoO}$ produced a material with high cyclic stability, high oxygen uptake ratio, and high energy conversion performance. The mixing of $100 \mathrm{wt} . \% \mathrm{Fe}_{3} \mathrm{O}_{4}$ with $50 \mathrm{wt} . \% \mathrm{MnO}+50 \mathrm{wt} . \% \mathrm{CoO}$ resulted in decreased oxygen uptake ratio, increased stability performance, increased the reaction temperature and decreased the gap in temperature for reduction-oxidation steps for the material thereby reducing the 
sensible energy loss during the heating and cooling steps of the material production process. The phase change and decomposition of iron oxide occurred at the very high temperatures. Increasing the oxygen exchange capacity on iron oxides during redox reaction had a clear adverse effect on the thermal performance of $\mathrm{MnO}$ and $\mathrm{CoO}$, and thereby leading to decrease in thermal enthalpy in the process. Thus, the development of new models covering large multi-component systems could further be used in selecting other transition metals to enhance the properties of mixed metal oxides for thermochemical energy storage application technology.

Author Contributions: Formal analysis, B.J.; Software, J.Z. and J.A.; Supervision, Q.H. and B.G.L.; Writing-original draft, Y.G.D.; Writing-review \& editing, E.B.T. All authors have read and agreed to the published version of the manuscript.

Funding: This work was funded by the National Natural Science Foundation of China (No. 51976044; 51950410590), China Postdoctoral Science Foundation Fund (2019M651284), and Fundamental Research Funds for the Central Universities (HIT.NSRIF.2020054)

Conflicts of Interest: The authors declare no conflict of interest and the funders had no role in the design of the study; in the collection, analyses, or interpretation of data; in the writing of the manuscript, or in the decision to publish the results.

\section{References}

1. Medrano, M.; Gil, A.; Martorell, I.; Potau, X.; Cabeza, L.F. State of the art on high-temperature thermal energy storage for power generation. Part 2-Case studies. Renew. Sustain. Energy Rev. 2010, 14, 56-72. [CrossRef]

2. Zalba, B.; Marín, J.M.; Cabeza, L.F.; Mehling, H. Review on thermal energy storage with phase change: Materials, heat transfer analysis and applications. Appl. Therm. Eng. 2003, 23, 251-283. [CrossRef]

3. Pardo, P.; Deydier, A.; Anxionnaz-Minvielle, Z.; Rougé, S.; Cabassud, M.; Cognet, P. A review on high temperature thermochemical heat energy storage. Renew. Sustain. Energy Rev. 2014, 32, 591-610. [CrossRef]

4. Yan, T.; Wang, R.Z.; Li, T.X.; Wang, L.W.; Fred, I.T. A review of promising candidate reactions for chemical heat storage. Renew. Sustain. Energy Rev. 2015, 43, 13-31. [CrossRef]

5. Farulla, G.A.; Cellura, M.; Guarino, F.; Ferraro, M. A review of the Thermochemical Emergy Storage Systems for Power Grid Support. Appl. Sci. Rev. 2020, 10, 3142. [CrossRef]

6. Pelay, U.; Luo, L.; Fan, Y.; Stitou, D.; Rood, M. Thermal energy storage systems for concentrated solar power plants. Renew. Sustain. Energy Rev. 2017, 79, 82-100. [CrossRef]

7. Ströhle, S.; Haselbacher, A.; Jovanovic, Z.R.; Steinfeld, A. The effect of the gas-solid contacting pattern in a high-temperature thermochemical energy storage on the performance of a concentrated solar power plant. Energy Environ. Sci. 2016, 9, 1375-1389. [CrossRef]

8. Bayon, A.; Bader, R.; Jafarian, M.; Fedunik-Hofman, L.; Sun, Y.; Hinkley, J.; Miller, S.; Lipiński, W. Techno-economic assessment of solid-gas thermochemical energy storage systems for solar thermal power applications. Energy 2018, 149, 473-484. [CrossRef]

9. André, L.; Abanades, S.; Flamant, G. Screening of thermochemical systems based on solid-gas reversible reactions for high temperature solar thermal energy storage. Renew. Sustain. Energy Rev. 2016, 64, 703-715. [CrossRef]

10. Fujii, I.; Tsuchiya, K.; Higano, M.; Yamada, J. Studies of an energy storage system by use of the reversible chemical reaction: CaO $+\mathrm{H}_{2} \mathrm{OCa}(\mathrm{OH})_{2}$. Sol. Energy 1985, 34, 367-377. [CrossRef]

11. Pardo, P.; Anxionnaz-Minvielle, Z.; Rougé, S.; Cognet, P.; Cabassud, M. Ca(OH) $/$ CaO reversible reaction in a fluidized bed reactor for thermochemical heat storage. Sol. Energy 2014, 107, 605-616. [CrossRef]

12. Linder, M.; Roßkopf, C.; Schmidt, M.; Wörner, A. Thermochemical energy storage in kW-scale based on $\mathrm{CaO} / \mathrm{Ca}(\mathrm{OH})_{2}$. Energy Procedia 2013, 49, 888-897. [CrossRef]

13. Dai, L.; Long, X.F.; Lou, B.; Wu, J. Thermal cycling stability of thermochemical energy storage system $\mathrm{Ca}(\mathrm{OH})_{2} / \mathrm{CaO}$. Appl. Therm. Eng. 2018, 133, 261-268. [CrossRef]

14. Criado, Y.A.; Huille, A.; Rougé, S.; Abanades, J.C. Experimental investigation and model validation of a $\mathrm{CaO} / \mathrm{Ca}(\mathrm{OH})_{2}$ fluidized bed reactor for thermochemical energy storage applications. Chem. Eng. J. 2017, 313, 1194-1205. [CrossRef]

15. Yan, J.; Zhao, C.Y. First-principle study of $\mathrm{CaO} / \mathrm{Ca}(\mathrm{OH})_{2}$ thermochemical energy storage system by $\mathrm{Li}$ or $\mathrm{Mg}$ cation doping. Chem. Eng. Sci. 2014, 117, 293-300. [CrossRef]

16. Criado, Y.A.; Alonso, M.; Abanades, J.C. Enhancement of a $\mathrm{CaO} / \mathrm{Ca}(\mathrm{OH})_{2}$ based material for thermochemical energy storage. Sol. Energy 2016, 135, 800-809. [CrossRef]

17. Ortiz, C.; Romano, M.C.; Valverde, J.M.; Binotti, M.; Chacartegui, R. Process integration of Calcium-Looping thermochemical energy storage system in concentrating solar power plants. Energy 2018, 155, 535-551. [CrossRef]

18. Chen, X.; Jin, X.; Liu, Z.; Ling, X.; Wang, Y. Experimental investigation on the $\mathrm{CaO} / \mathrm{CaCO}_{3}$ thermochemical energy storage with $\mathrm{SiO}_{2}$ doping. Energy 2018, 155, 128-138. [CrossRef] 
19. Benitez-Guerrero, M.; Valverde, J.M.; Sanchez-Jimenez, P.E.; Perejon, A.; Perez-Maqueda, L.A. Multicycle activity of natural $\mathrm{CaCO}_{3}$ minerals for thermochemical energy storage in Concentrated Solar Power plants. Sol. Energy 2017, 153, 188-199. [CrossRef]

20. André, L.; Abanades, S. Evaluation and performances comparison of calcium, strontium and barium carbonates during calcination/carbonation reactions for solar thermochemical energy storage. J. Energy Storage 2017, 13, 193-205. [CrossRef]

21. Wu, S.; Zhou, C.; Doroodchi, E.; Nellore, R.; Moghtaderi, B. A review on high-temperature thermochemical energy storage based on metal oxides redox cycle. Energy Convers. Manag. 2018, 168, 421-453. [CrossRef]

22. Bulfin, B.; Vieten, J.; Agrafiotis, C.; Roeb, M.; Sattler, C. Applications and limitations of two step metal oxide thermochemical redox cycles: A review. J. Mater. Chem. A 2017, 5, 18951-18966. [CrossRef]

23. Alonso, E.; Pérez-Rábago, C.; Licurgo, J.; Fuentealba, E.; Estrada, C.A. First experimental studies of solar redox reactions of copper oxides for thermochemical energy storage. Sol. Energy 2015, 115, 297-305. [CrossRef]

24. Haseli, P.; Jafarian, M.; Nathan, G.J. High temperature solar thermochemical process for production of stored energy and oxygen based on $\mathrm{CuO} / \mathrm{Cu}_{2} \mathrm{O}$ redox reactions. Sol. Energy 2017, 153, 1-10. [CrossRef]

25. Hänchen, M.; Stiel, A.; Jovanovic, Z.R.; Steinfeld, A. Thermally driven copper oxide redox cycle for the separation of oxygen from gases. Ind. Eng. Chem. Res. 2012, 51, 7013-7021. [CrossRef]

26. Clayton, C.K.; Whitty, K.J. Measurement and modeling of decomposition kinetics for copper oxide-based chemical looping with oxygen uncoupling. Appl. Energy 2014, 116, 416-423. [CrossRef]

27. Alonso, E.; Pérez-Rábago, C.; Licurgo, J.; Gallo, A.; Fuentealba, E.; Estrada, C.A. Experimental aspects of CuO reduction in solar-driven reactors: Comparative performance of a rotary kiln and a packed bed. Renew. Energy 2017, 105, 665-673. [CrossRef]

28. Schrader, A.J.; Muroyama, A.P.; Loutzenhiser, P.G. Solar electricity via an Air Brayton cycle with an integrated two-step thermochemical cycle for heat storage based on $\mathrm{Co}_{3} \mathrm{O}_{4} / \mathrm{CoO}$ redox reactions: Thermodynamic analysis. Sol. Energy 2015, 118, 485-495. [CrossRef]

29. Singh, A.; Tescari, S.; Lantin, G.; Agrafiotis, C.; Roeb, M.; Sattler, C. Solar thermochemical heat storage via the $\mathrm{Co}_{3} \mathrm{O}_{4} / \mathrm{CoO}$ looping cycle: Storage reactor modelling and experimental validation. Sol. Energy 2017, 144, 453-465. [CrossRef]

30. Abedin, A.H.; Rosen, M.A. A critical review of thermochemical energy storage systems. Open Renew. Energy 2011, 4, 42-46. [CrossRef]

31. Yuan, Y.; Ruan, Z.-H.; Huang, X.; Jiang, Y.-Q.; Tan, H.-P. Energy-absorption-based explanation of the $\mathrm{TiO}_{2} / \mathrm{C}$ photocatalytic activity enhancement mechanism. J. Catal. 2017, 348, 246-255. [CrossRef]

32. Fuqiang, W.; Ziming, C.; Jianyu, T.; Yuan, Y.; Yong, S.; Linhua, L. Progress in concentrated solar power technology with parabolic trough collector system: A comprehensive review. Renew. Sustain. Energy. Rev. 2017, 79, 1314-1328. [CrossRef]

33. Block, T.; Knoblauch, N.; Shmücker, M. The cobalt-oxide/iron-oxide binary system for use as high temperature thermochemical energy storage material. Thermochim. Acta 2014, 577, 25-32. [CrossRef]

34. Agrafiotis, C.; Roeb, M.; Schücker, M.; Sattler, C. Exploitation of thermochemical cycles based on solid oxide redox systems for thermochemical storage of solar heat. Part 2: Redox oxide-coated porous ceramic structures as integrated thermochemical reactors/heat exchangers. Sol. Energy 2015, 114, 440-458. [CrossRef]

35. Agrafiotis, C.; Tescari, S.; Roeb, M.; Schücker, M.; Sattler, C. Exploitation of thermochemical cycles based on solid oxide redox systems for thermochemical storage of solarheat.Part 3: Cobaltoxide monolithic porous structures as integrated thermochemical reactors / heat exchanger. Sol. Energy 2015, 114, 459-475. [CrossRef]

36. Neises, M.; Tescari, S.; DeOliveira, L.; Roeb, M.; Sattler, C.; Wong, B. Solar-heated rotary kilnfor thermochemical energy storage. Sol. Energy 2012, 86, 3040-3048. [CrossRef]

37. Tescari, S.; Agrafiotis, C.; Breuer, S.; DeOliveira, L.; Nieses-vonPuttkamer, M.; Roeb, M.; Sattler, C. Thermochemical solar energy storage varied oxides: Materials and reactor/heat exchanger concepts. Energy Procedia 2014, 49, 1034-1043. [CrossRef]

38. Karagiannakis, G.; Pagkoura, C.; Zygogianni, A.; Lorentzou, S.; Konstandopoulos, A.G. Monolithic ceramic redox materials for thermochemical heat storage applications in CSP plants. Energy Procedia 2014, 49, 820-829. [CrossRef]

39. Carrillo, A.J.; Serrano, D.P.; Pizarro, P.; Coronado, J.M. Improving the thermo- chemical energy storage performance of the $\mathrm{Mn}_{2} \mathrm{O}_{3} / \mathrm{Mn}_{3} \mathrm{O}_{4}$ redox couple by the incorporation of iron. ChemSusChem 2015, 8, 1947-1954. [CrossRef]

40. Pagkoura, C.; Karagiannakis, G.; Zygogianni, A.; Lorentzou, S.; Kostoglou, M.; Konstandopoulos, A.G.; Rattenburry, M.; Woodhead, W.J. Cobalt oxide based structured bodies as redox thermochemical heat storage medium for future CSP plants. Sol. Energy 2014, 108, 146-163. [CrossRef]

41. Carrillo, A.J.; Serrano, D.P.; Pizarro, P.; Coronado, J.M. Thermochemical heat storage based on the $\mathrm{Mn}_{2} \mathrm{O}_{3} / \mathrm{Mn}_{3} \mathrm{O}_{4}$ redox couple: Influence of the initial particle on the morphological evolution and cyclability. J. Mater. Chem. A 2014, 2, 19435-19443. [CrossRef]

42. Jung, I.H.; Decterov, S.A.; Pelton, A.D.; Kim, H.M.; Kang, Y.B. Thermodynamic evaluation and modeling of the Fe-Co-O system. Acta Mater. 2004, 52, 507-519. [CrossRef]

43. Zhang, W.-W.; Chen, M. Thermodynamic modeling of the Co-Fe-O system. Calphad 2013, 41, 76-88. [CrossRef]

44. Kang, Y.B.; Jung, I.H. Thermodynamic modeling of oxide phases in the Fe-Mn-O system. J. Phys. Chem. Solids 2016, 98, 237-246. [CrossRef]

45. Kjellqvist, L.; Selleby, M. Thermodynamic assessment of the Fe-Mn-O system. J. Phase Equilibria Diffus. 2010, 31, 113-134. [CrossRef] 
46. Guene Lougou, B.; Shuai, Y.; Guohua, Z.; Chaffa, G.; Ahouannou, C.; Tan, H. Analysis of $\mathrm{H}_{2}$ and CO production via solar thermochemical reacting system of $\mathrm{NiFe}_{2} \mathrm{O}_{4}$ redox cycles combined with $\mathrm{CH} 4$ partial oxidation. Int. J. Hydrog. Energy 2018, 43, 5996-6010. [CrossRef]

47. Lougou, B.G.; Shuai, Y.; Chaffa, G.; Ahouannou, C.; Pan, R.; Zhang, H.; Tan, H. Analysis of two-step solar thermochemical looping reforming of $\mathrm{Fe}_{3} \mathrm{O}_{4}$ redox cycles for synthesis gas production. Energy Technol. 2018, 7, 1800588. [CrossRef]

48. Lougou, B.G.; Shuai, Y.; Pan, R.; Chaffa, G.; Tan, H. Heat transfer and fluid flow analysis of porous medium solar thermochemical reactor with quartz glass cover. Int. J. Heat. Mass. Transf. 2018, 127, 61-74. [CrossRef]

49. Lougou, B.G.; Shuai, Y.; Pan, R.; Chaffa, G.; Ahouannou, C.; Zhang, H.; Tan, H. Radiative heat transfer and thermal characteristics of Fe-based oxides coated $\mathrm{SiC}$ and Alumina RPC structures as integrated solar thermochemical reactor. Sci. China Technol. Sci. 2018, 61, 1788-1801. [CrossRef]

50. Guene Lougou, B.; Han, D.; Zhang, H.; Jiang, B.; Anees, J.; Ahouannou, C.; Zhao, J.; Shuai, Y. Numerical and experimental analysis of reactor optimum design and solar thermal-chemical energy conversion for multidisciplinary applications. Energy Convers. Manag. 2020, 213, 112870. [CrossRef]

51. Shuai, Y.; Zhang, H.; Guene Lougou, B.; Jiang, B.; Mustafa, A.; Wang, C.-H.; Wang, F.; Zhao, J. Solar-driven thermochemical redox cycles of $\mathrm{ZrO}_{2}$ supported $\mathrm{NiFe}_{2} \mathrm{O}_{4}$ for $\mathrm{CO}_{2}$ reduction into chemical energy. Energy 2021, 223, 120073. [CrossRef]

52. Shuai, Y.; Guene Lougou, B.; Zhang, H.; Zhao, J.; Ahouannou, C.; Tan, H. Heat transfer analysis of solar-driven high-temperature thermochemical reactor using NiFe-Aluminate RPCs. Int. J. Hydrog. Energy 2021, 46, 10104-10118. [CrossRef]

53. Getahun Dessie, Y.; Guene Lougou, B.; Qi, H.; Tan, H. Reactor Design and Thermal Performance Analysis for Solar Thermal Energy Storage Application. Energies 2020, 13, 3186. [CrossRef]

54. Getahun Dessie, Y.; Guene Lougou, B.; Qi, H.; Tan, H.; Zhang, J.; Gao, B.; Islam, M.A. Thermal Performance Analysis of a Solar Reactor Designed for Syngas Production. Energies 2020, 13, 3405. [CrossRef]

55. Guene Lougou, B.; Shuai, Y.; Zhang, $\mathrm{H}$. Thermochemical $\mathrm{CO}_{2}$ reduction over $\mathrm{NiFe}_{2} \mathrm{O}_{4} @$ alumina filled reactor heated by high-flux solar simulator. Energy 2020, 197, 117267. [CrossRef]

56. Serra, R.; Nomen, R.; Sempere, J. The non-parametric kinetics a new method for the kinetic study of thermoanalytical data. $J$. Thermal. Anal. Calorim. 1998, 52, 933-943. [CrossRef]

57. Serra, R.; Sempere, J.; Nomen, R. A new method for the kinetic study of thermoanalytical data: The nonparametric kinetics method. Thermochim. Acta 1998, 316, 37-45. [CrossRef]

58. Sempere, J.; Nomen, R.; Serra, R.; Soravilla, J. The NPK method-An innovative approach for kinetic analysis of data from thermal analysis and calorimetry. Thermochim. Acta 2002, 388, 407-414. [CrossRef] 